\title{
Article \\ Monitoring of Heavy Metals and Nitrogen Concentrations in Mosses in the Vicinity of an Integrated Iron and Steel Plant: Case Study in Czechia
}

\author{
Irena Pavlíková ${ }^{1,2, *(\mathbb{D},}$, Oldřich Motyka ${ }^{3,4}$ (D) Vítězslav Plášek ${ }^{5}\left(\mathbb{D}\right.$ and Jan Bitta ${ }^{1}$ (D) \\ 1 Department of Environmental Protection in Industry, Faculty of Materials Science and Technology, \\ VSB-Technical University of Ostrava, 70800 Ostrava, Czech Republic; jan.bitta@vsb.cz \\ 2 Sector of Neutron Activation Analysis and Applied Research, Frank Laboratory of Neutron Physics, Joint \\ Institute for Nuclear Research, 141980 Dubna, Russia \\ 3 Nanotechnology Centre, CEET, VSB-Technical University of Ostrava, 70800 Ostrava, Czech Republic; \\ oldrich.motyka@vsb.cz \\ 4 ENET Centre, CEET, VSB-Technical University of Ostrava, 70800 Ostrava, Czech Republic \\ 5 Department of Biology and Ecology, Faculty of Science, University of Ostrava, 71000 Ostrava, Czech \\ Republic; vitezslav.plasek@osu.cz \\ * Correspondence: irena.pavlikova@vsb.cz; Tel.: +420-604-636-041
}

check for updates

Citation: Pavlíková, I.; Motyka, O.; Plášek, V.; Bitta, J. Monitoring of Heavy Metals and Nitrogen

Concentrations in Mosses in the Vicinity of an Integrated Iron and Steel Plant: Case Study in Czechia. Appl. Sci. 2021, 11, 8262. https:// doi.org/10.3390/app11178262

Academic Editors: Antoaneta Ene and Claudia Stihi

Received: 17 August 2021

Accepted: 2 September 2021

Published: 6 September 2021

Publisher's Note: MDPI stays neutral with regard to jurisdictional claims in published maps and institutional affiliations.

Copyright: (c) 2021 by the authors. Licensee MDPI, Basel, Switzerland. This article is an open access article distributed under the terms and conditions of the Creative Commons Attribution (CC BY) license (https:// creativecommons.org/licenses/by/ $4.0 /)$.
Featured Application: The findings of this study can be applied in monitoring of atmospheric deposition of heavy metals and nitrogen on a local scale in order to better understand the pollution distribution in the surroundings of a local pollution source, especially in the context of the interpretation of the results respecting the principle's compositional data analyses.

Abstract: A biomonitoring study using terrestrial mosses was performed in the vicinity of an Integrated Iron and Steel plant near the Czech-Polish border. Moss samples were collected in two seasons (June, October) in order to embrace the effect of the heating season on the pollution levels. The contents of metals ( $\mathrm{Al}, \mathrm{V}, \mathrm{Cr}, \mathrm{Mn}, \mathrm{Fe}, \mathrm{Ni}, \mathrm{Cu}, \mathrm{Zn}, \mathrm{Cd}, \mathrm{Pb}, \mathrm{As}, \mathrm{Sb}$ and $\mathrm{Hg}$ ) were determined using the Inductively Coupled Plasma-Atomic Emission Spectroscopy (ICP-AES), Atomic Absorption Spectroscopy (AAS) and contents of N, C, H via elemental analysis. The influence of the proximity of the factory, the heating season and modelled concentrations of particulate matter $<10 \mu \mathrm{m}\left(\mathrm{PM}_{10}\right)$ on determined concentrations of elements were studied via multivariate statistical methods using clr-transformed data. This approach led to the first-time demonstration that not only the distance from the industrial source but also the sampling season and $\mathrm{PM}_{10}$ concentrations significantly affect the elemental content in mosses; the association of the emissions from the source and the determined concentrations of elements in moss samples were more evident outside the heating season (October). The analyses of transformed data revealed the association of $\mathrm{Fe}, \mathrm{Cr}, \mathrm{V}$, As and $\mathrm{Al}$ with the coarse particles and their dominant spatial distribution depending on the prevailing wind directions. The spatial distribution of $\mathrm{Mn}, \mathrm{Zn}$ and $\mathrm{Cd}$, which are carried by fine particles, appears to depend more on atmospheric dispersion and long-range transport, and, thus, these metals should be considered weak markers of the pollution load in the close surroundings of an industrial source.

Keywords: air pollution; biomonitoring; moss; iron plant; steel plant; seasonal variation; compositional data analysis; centered-log ratio transformation; Třinec; Czechia

\section{Introduction}

Ambient air pollution remains one of the main global environmental concerns presenting significant risks for both human health and vulnerable ecosystems [1-3]. The air pollution in the Czech Republic (CR), especially in the north-eastern part of the country, exceeds the legal limit values (LV) in the long term, and thus the region represents one of the biggest air pollution hotspots in all of Europe [3-6]. 
The main causes of this unfavourable situation are mostly historically connected to emissions from coal-burning in domestic heating (in both Czechia and neighbouring Poland) and significant industrial emissions associated with black coal mining and heavy industry, represented by energetics, iron and steelmaking plants and coking plants [3,5,7]. Furthermore, emissions from these pollution sources with high stacks and significant power contribute to the pollution of a much larger area due to long-range transport and may present risks to ecosystems in other European regions [5,8]. Unsatisfying air quality and legislation changes [9-11] led to the application of various measures aiming at emission reduction and modernisation of the industry in the region, alongside with extensive support of the modernisation of domestic boilers. Nevertheless, although the overall air quality has improved substantially, the concentrations of particulate matter $\left(\mathrm{PM}_{10}\right.$ and $\left.\mathrm{PM}_{2,5}\right)$, ground-level ozone $\left(\mathrm{O}_{3}\right)$ and benzo[a]pyrene $(\mathrm{BaP})$ still exceed the $\mathrm{LV}$, affecting the population and ecosystems in the area. The heavy industry represented by iron and steel production remains one of the most important industrial sources of pollution in the region.

An integrated steel production includes a large complex of technologies from transporting raw materials, modification of their physical and chemical properties (coking and sintering), iron making (blast furnace process), primary steel making (basic oxygen furnaces or electric arc furnaces processes), secondary steelmaking (casting, forming and finishing) to processing of the main metallurgical waste products such as slags and gases [12]. Large amounts of raw materials and energy needed for iron and steelmaking processes result in a substantial amount of waste products (solid, liquid and gaseous) with a negative environmental impact, comprising mainly hazardous and solid wastes, wastewater contamination and air emissions (such as carbon oxides $\left(\mathrm{CO}, \mathrm{CO}_{2}\right)$ [13], sulphur oxides $\left(\mathrm{SO}_{\mathrm{x}}\right)$, nitrogen oxides $\left(\mathrm{NO}_{\mathrm{x}}\right)$, particulate matter $(\mathrm{PM})$, heavy metals $(\mathrm{HM})$ and polycyclic aromatic hydrocarbons (PAH)) [14]. The air pollutants are deposited onto the surrounding landscape in the form of dry or wet deposition, having adverse effects on both the ecosystem and human health [2,15-17]. Pollution transport range depends on emitter characteristics, physical and chemical properties of the pollutant and meteorological conditions [18-20]. While mineral particles are deposited within the vicinity of the source, aerosols or gaseous emissions can be transported on long distances [8,21]. Thus, heavy metals bound to and carried by particulate matter [22-24] enter the environment closer or farther from their source, mainly depending on the aerodynamic diameter of carriers [18,20].

The environmental load of heavy metals originating in air emissions can be monitored through passive biomonitoring using moss since dense carpets of naturally growing pleurocarpous species are effective traps of pollution present both in airborne particles and precipitation $[25,26]$. Moreover, the biomonitoring technique was proven suitable for a long-range pollution transport evaluation [27-30] as well as for local pollution source assessment (for example: [31-40]).

The objective of this study was to assess the spatial and seasonal variability of heavy metals and other supplementary elements in the moss tissue of Brachythecium rutabulum in the environment surrounding integrated steel mills-the Třinec Iron and Steel Works (Czechia). The concentrations of aluminium (Al), arsenic (As), cadmium (Cd), chromium $(\mathrm{Cr})$, copper $(\mathrm{Cu})$, iron $(\mathrm{Fe})$, mercury $(\mathrm{Hg})$, manganese $(\mathrm{Mn})$, nickel $(\mathrm{Ni})$, lead $(\mathrm{Pb})$, antimony $(\mathrm{Sb})$, vanadium $(\mathrm{V})$, zinc $(\mathrm{Zn})$ and nitrogen $(\mathrm{N})$ were analysed (additionally carbon $(\mathrm{C})$ and hydrogen $(\mathrm{H})$ ). The survey was carried out following the European norm EN 16,414 Ambient air-Biomonitoring with mosses [41]. Additionally, the relationship between the composition of the moss analysed and modelled seasonal atmospheric particulate matter concentrations $\left(\mathrm{PM}_{10}\right)$ originating in anthropogenic sources were explored. We hypothesised that the element concentrations in moss tissues would be influenced by the heating season, would decrease with the distance from the factory along the prevailing wind direction [33,42-44] and would be significantly correlated to the modelled $\mathrm{PM}_{10}$ concentrations $[45,46]$. 


\section{Experiments}

\subsection{Study Area}

The area of interest is situated in the Moravian-Silesian Region in the northeast of Czechia, bordering Poland. It consists of the Trrinec Trough lying along the Olza River, surrounded by the Silesian Beskids from the northeast (up to $700 \mathrm{~m}$ above sea level) and the Moravian-Silesian Beskids from the southwest (up to $1000 \mathrm{~m}$ above sea level). In the centre of the region, the town of Trrinec is situated (WGS84: 49.677892N, 18.670754E) with a population of about 35,000 inhabitants (Czech Statistical Office, Czechia, 2020). See Figure 1.

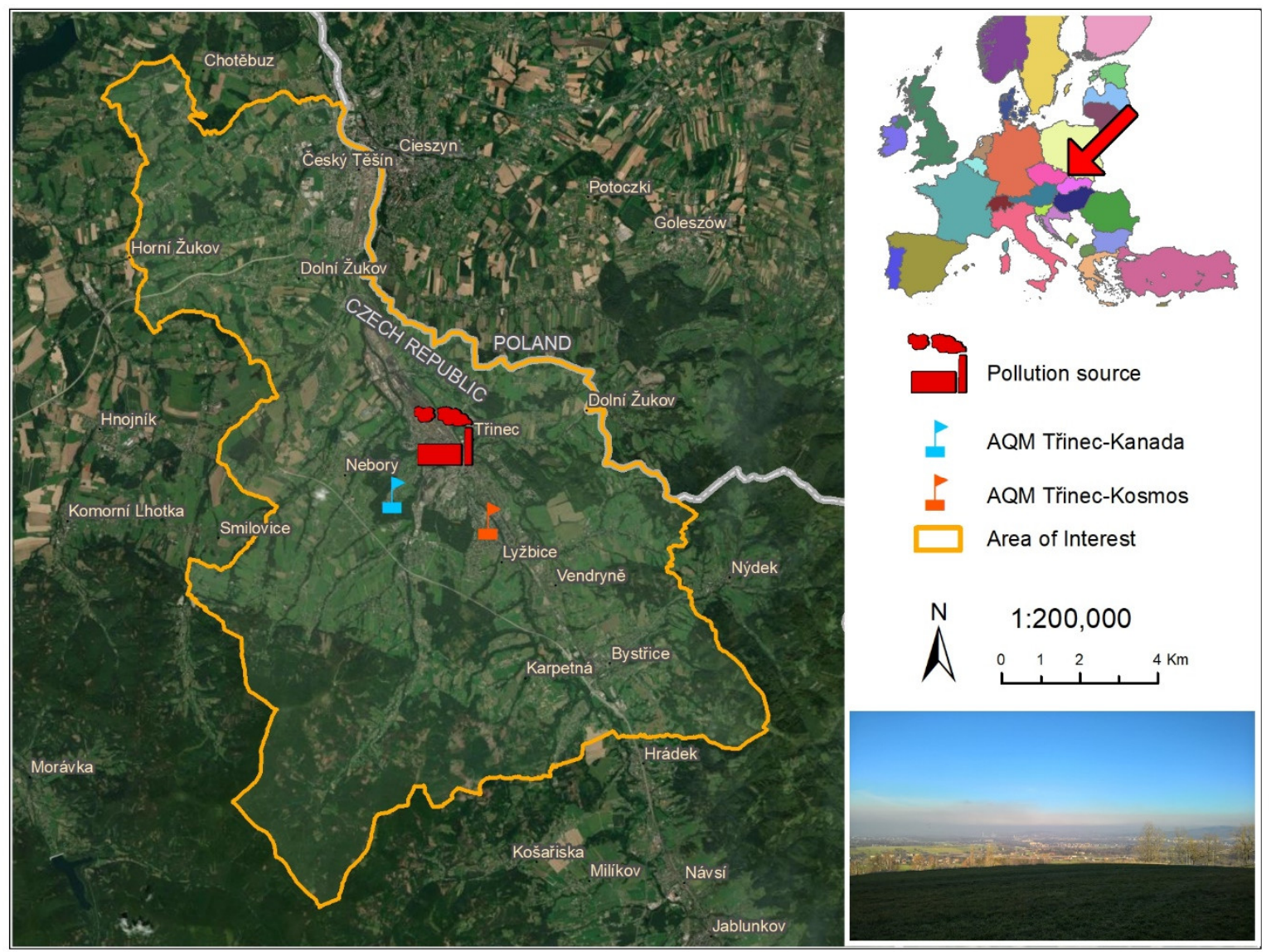

Figure 1. Situation map of the area of interest (AQM-air quality monitoring).

According to the Köppen climate classification [47,48], most of the area belongs to the climate group $C f b$-Temperate oceanic climate with the coldest month averaging temperature above $0{ }^{\circ} \mathrm{C}$, all months with average temperatures below $22^{\circ} \mathrm{C}$, and at least four months averaging above $10^{\circ} \mathrm{C}$. There is no significant precipitation difference between seasons. A small part of the area covering the Moravian-Silesian Beskids comes under the groups $D f b$-Warm-summer humid continental climate (with similar climate characteristics as $C f b$ ) and $D f c-S u b a r c t i c$ climate. According to the Czech Hydrometeorological Institute (CHMI), the normal annual sum of precipitation (1981-2010) in the area ranges between 800 and $1000 \mathrm{~mm}$, exceeding the Czech average significantly.

The modern history of Třinec city is inseparably connected with iron and steelmaking. The Třinec Iron and Steel Works (WGS84: 49.6903064N, 18.6484139E) have operated since 1839, and, nowadays, it is the second-largest factory of its kind in Czechia, producing about $2000 \mathrm{kt}$ of pig iron and $2500 \mathrm{kt}$ of crude steel per year [49]. Though PM emissions associated with the production are in a long-term decline, the factory remains an important source of pollution (see Figure 2). 


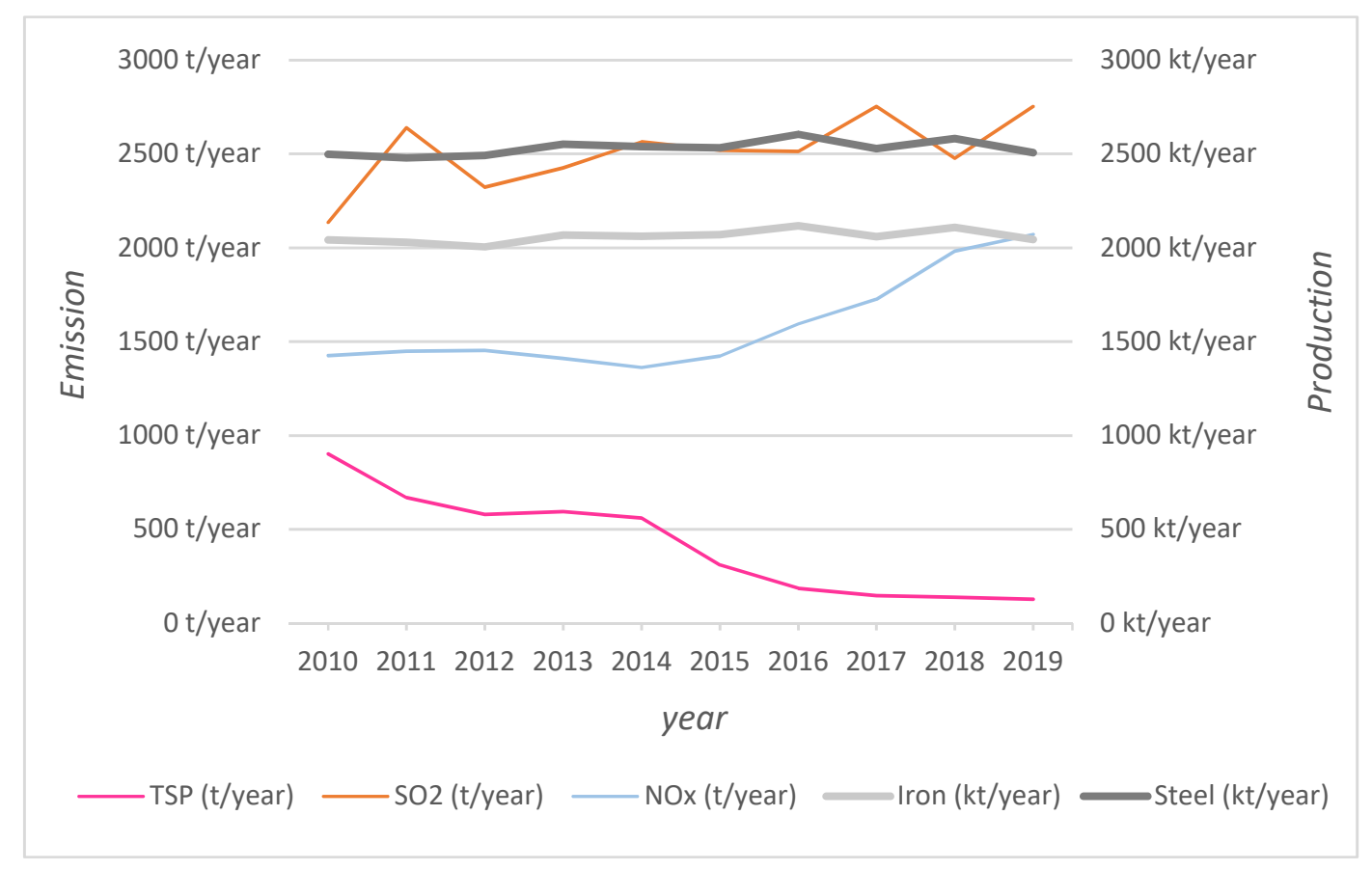

Figure 2. Emissions and production of the Třinec Iron and Steel Works.

The Třinec Iron and Steel Works and the surrounding area were chosen for the study because they were found to correspond well with the main objectives. The factory is situated in a narrow valley with clear prevailing wind directions, which enables the study of the spatial distribution of pollution in a relatively closed area. The PM emissions of the Trrinec Iron and Steel Works dropped to $15 \%$ of the original values in the last decade (Figure 2), which should entail a considerably lower pollution load of the surrounding environment. Moreover, within the distance of $5 \mathrm{~km}$, the border of the protected area of Beskids is located, representing a vulnerable environment that should be taken under consideration, too.

The pollution in the area is measured by two air quality monitoring stations (AQM): Třinec-Kanada station (WGS84: 49.672402N, 18.643058E), monitoring $\mathrm{NO}, \mathrm{NO}_{2}, \mathrm{NO}_{\mathrm{x}}, \mathrm{PM}_{2.5}$ and $\mathrm{PM}_{10}$ concentrations, and Třinec-Kosmos station (WGS84: 49.668123N, 18.677791E), monitoring $\mathrm{O}_{3}, \mathrm{PM}_{2.5}$ and $\mathrm{PM}_{10}$ concentrations [50]. However, information on heavy metal concentration is absent, which presents one of the motivations for performing this survey. In 2017 (when the biomonitoring was performed), the daily $\mathrm{PM}_{10}$ concentrations surpassed the tolerated number of exceedance (TE), and the annual average $\mathrm{PM}_{2.5}$ concentrations surpassed the legal limit values of $20 \mu \mathrm{g} \cdot \mathrm{m}^{-3}[3,51]$. When the PM concentrations are displayed in relation to wind direction (see Figure 3), it suggests that the most important source of the pollutant is the nearby factory. Though the last published data from 2019 revealed that LVs for observed pollutants were met, according to the CHMI, it was mainly due to exceptionally favourable meteorological conditions and an overall decrease of emissions in the region [50]. 


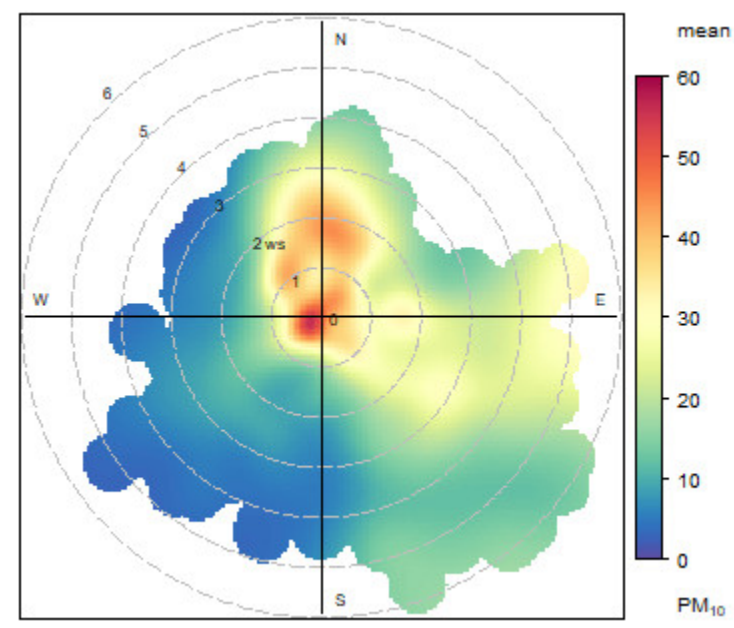

(a)

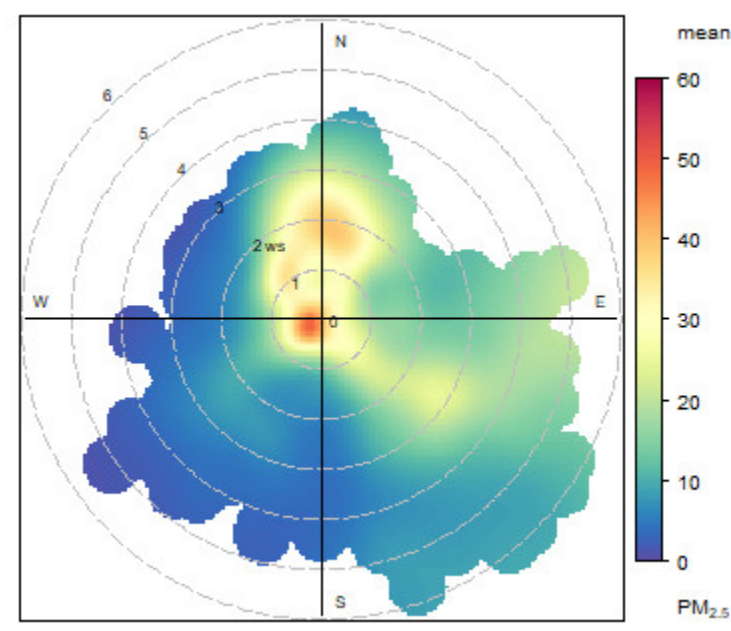

(b)

Figure 3. $\mathrm{PM}_{10}$ pollution rose (a); $\mathrm{PM}_{2.5}$ pollution rose (b) at AQM Třinec-Kanada in 2017 (data CHMI [52,53]).

\subsection{Sampling}

The design of a sampling network and sampling and sample treatment were completed according to the European standard EN 16,414 [41] and respecting the Moss Sampling Manual of the International Cooperative Programme on Effects of Air Pollution on Natural Vegetation and Crops (ICP Vegetation) [30].

For assessment of a local pollution source, the norm suggests locating sampling points around a source in respect to the direction of the prevailing wind while at least three points should be located on a straight line from a source in the direction of the prevailing wind; two other points in the opposite direction and two leeward, in a greater distance, with a minimal effect from a source. The sampling network was designed respecting these guidelines and based on prevailing wind direction, topography and altitude in the area. The network resulted in 14 sampling sites, as can be seen in Figure 4. The points were located around the primary source of pollution, both in the direction (southeast direction) and in the opposite direction (northwest) of the prevailing wind, but also at a higher altitude (south-south-west-on the hillside of the Javorový hill (748 $\mathrm{m}$ above sea level) and in the opposing direction (leeward) on the Osůvka hill (400 m above sea level). Moss samples were collected in the created network with respect to the presence of the moss; the actual locations of sampling points were recorded using GPS.

The sampling took place in two seasons in order to investigate the influence of the heating season on the concentrations of analysed elements. The samples supposedly under the influence of sources connected to the heating season were collected in June (hereinafter referred to as a summer sampling); the sampling of samples supposedly out of the influence of the heating season was performed in October (referred to as an autumn sampling) [54]. Both samplings were performed within 1 day, namely, on 27 June 2017 and 26 October 2017. If possible, moss was collected from tree stumps or dead wood to avoid contamination by soil particles and out of a tree canopy [55-58]. Based on field investigation and species occurrence, Brachythecium rutabulum (Hedw.) was chosen for the study. 


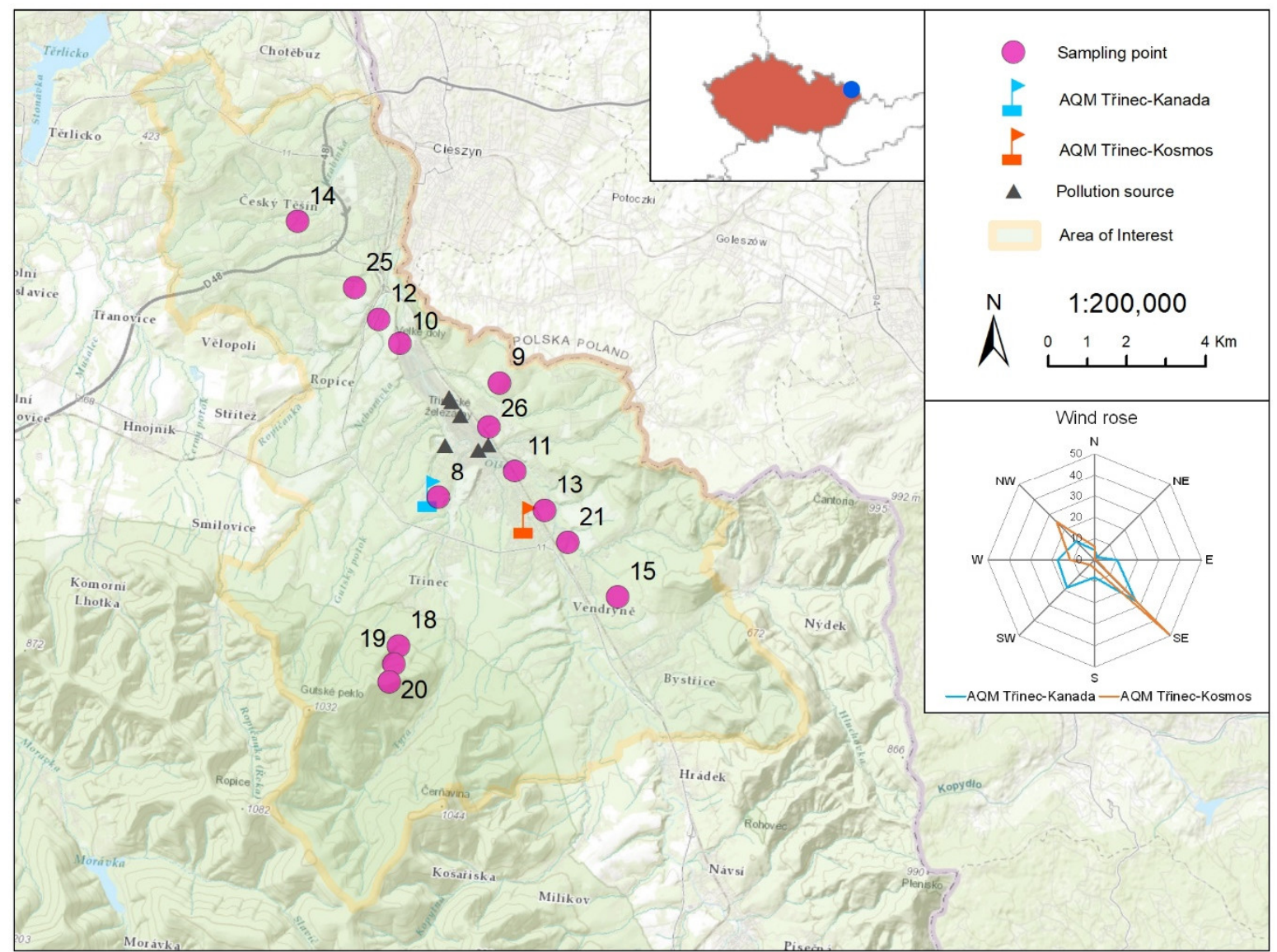

Figure 4. The sampling network and the wind rose.

Brachythecium rutabulum is a large pleurocarpous moss growing in lax, glossy, bright green or yellowish-green tufts or patches. It is common in Europe and occurs in many habitats, such as soil (both in woodland and non-forest vegetation), tree trunks, logs, stones and rock walls [59]. This species has been previously successfully used in large scale biomonitoring surveys, mainly in Poland and Southern Europe [36,60-62].

One of the basic preconditions for the selection of species for biomonitoring is their absorption capacity. The water absorption ratio in bryophytes depends mainly on the spatial structure of their cushions, which is considerably dense in Brachythecium rutabulum. Thanks to this feature, it suits the performed research well. The absorption capacity of dry B. rutabulum is 16.1:1, meaning that the dried plants can absorb an average of $20 \mathrm{~g}$ of water with dissolved substances per $1 \mathrm{~g}$ of herb [63]. For comparison, this amount is about $75 \%$ of the value the cushions of the genus Sphagnum (who are record holders in this respect) can absorbed.

As Brachythecium rutabulum was not present on all sampling sites, one sample in each season is covered by Hypnum cupressiforme. Detailed information on samples can be found in Supplementary Materials Table S1.

\subsection{Sample Analyses}

Collected samples were transported to the laboratory, where they were dried at constant ambient temperature $\left(20^{\circ} \mathrm{C}\right)$ for $24 \mathrm{~h}$ and immediately processed. All extraneous material (plant and tree remains, visible particles) was manually removed, and green apical segments (up to $2 \mathrm{~cm}$ in length) were cut from shoots. Prior to the chemical analyses, samples were dried to a constant weight at $40{ }^{\circ} \mathrm{C}$ and pulverised using an agate mill (>3 min, $350 \mathrm{rpm}$ ).

The prepared samples were subjected to the elemental analysis on Leco CHN628 following the Dumas method (combustion technique) [64]. Quality management was 
ensured using certified reference material (CRM), CHN coal, ethylenediaminetetraacetic acid (EDTA) and/or phenylalanine (Phe) (Leco). The recovery from reference material was above $90 \%$. Samples were duplicated in order to examine the precision of the analysis. A deviation below $7.1 \%$ was obtained for the first batch of samples collected in June and $9.4 \%$ for the second batch collected in October.

The concentrations of $\mathrm{Hg}$ in samples were determined using the Advanced Mercury Analyser AMA 254 based on thermal decomposition of samples and collection of originating $\mathrm{Hg}$ vapour on a gold amalgamator. The reference material used was qMETRANAL08, Green algae (ANALYTIKA, LTD., Czechia). The recovery from reference material was above $90 \%$.

For further analyses, the pulverised moss samples were thermally decomposed with an $\mathrm{HF}+\mathrm{H}_{2} \mathrm{SO}_{4}+\mathrm{HNO}_{3}$ mixture of concentrated acids (analytical grade pure). Blank samples were prepared simultaneously. The concentration of $\mathrm{Al}, \mathrm{V}, \mathrm{Cr}, \mathrm{Mn}, \mathrm{Fe}, \mathrm{Ni}, \mathrm{Cu}$, $\mathrm{Zn}, \mathrm{Cd}$ and $\mathrm{Pb}$ were determined using atomic emission spectroscopy with inductively coupled plasma (AES-ICP) SPECTRO Ciros Vision; an axial Ar/Ar plasma torch system; a cross-flow nebuliser and a Scott spray chamber was used for determination. The intensity in the 125-770 nm spectral range was measured simultaneously using CCD detectors. The calibration solutions and standards were prepared from store solution standards for AESICP (1 g.L ${ }^{-1}$, Merck). The complete information on the recovery of respective elements can be found in Supplementary Materials Table S1. All control standards were analysed after every 10 samples. Arsenic and antimony levels were determined using atomic absorption spectrometry (AAS) Unicam Solar 989 QZ. The recovery for As was above $92 \%$ and for $\mathrm{Sb}$ above $80 \%$. Arsenic and antimony were detected only in $39 \%$ and $29 \%$ of samples, respectively; other values were below detection. As values under the detection limit (UDL) cause problems in multivariate statistical analysis, the missing values were imputed using an algorithm (see below).

The complete results of chemical analyses can be found in Supplementary Materials Table S1.

\subsection{Statistical Analyses and Visualisation}

Pearson correlations calculation, Principal Component Analysis (PCA) and the visualisations of the results were performed in the R environment [65], packages compositions [66], robCompositions [67,68], FactoMineR [69,70] corrplot [71] and OpenAir [72]; maps were created by ESRI ArcGIS Desktop, version 10.5.0.6491, using open source basemaps provided by ESRI (World Imagery [73], World Topographic Map [74]).

Because the multivariate analysis has to be performed on complete datasets and zero values or fractions of detection limits are inappropriate [75], measurements under the detection limit were imputed using expectation-maximisation-based replacement by the ImpRZilr algorithm. Prior to the PCA, the data were transformed according to the Compositional data analysis (CoDa) principles [76,77] using the centred log-ratio (clr) transformation, the approach that was proven to be appropriate recently $[45,78,79]$. Only the clr-transformed elemental concentration data were used for the construction of the model. The information on the season, the distance of a sampling site from the dominant source and its orientation to it (downwind/other), together with modelled $\mathrm{PM}_{10}$ values for the individual sites, were added as supplementary variables. Original—untransformeddata were also projected on the PCA results to facilitate interpretation of the dimensions in terms of recorded element concentrations.

For the individual seasons, the PCA on clr-transformed data was also performed, this time with no supplementary variables. On its results, Hierarchical Clustering on Principal Components was performed to reveal the similarities in sampling points.

\subsection{Modelling of PM Concentrations}

Measured concentrations of respective elements in a moss tissue are supposed to be the function of their atmospheric deposition; they are usually correlated with the Euro- 
pean Monitoring and Evaluation Programme (EMEP) deposition modelling results [80-83]. However, the annual average EMEP data on atmospheric deposition have the resolution of a $0.1^{\circ} \times 0.1^{\circ}$ longitude-latitude grid, which is not sufficient for such a local study and-as it was proven previously-the particulate matter concentrations originating from anthropogenic sources are reflected in moss [45,46]; modelling of $\mathrm{PM}_{10}$ concentrations was performed. The Czech reference methodology SYMOS'97 [84,85] based on Sutton's theory of turbulent diffusion [71] was used for modelling. Season-specific airborne $\mathrm{PM}_{10}$ concentrations were modelled as the pollution in the area can be significantly influenced by domestic heating during the winter period $[3,86]$. Thus, air pollution modelling was run to obtain average winter season $\mathrm{PM}_{10}$ concentrations and average summer season $\mathrm{PM}_{10}$ concentrations on receptors located at the moss sampling sites. The seasonal data on respective sources (industry, transport, households) and meteorological data were used. The input data for the modelling were acquired from the CHMI databases (emissions, meteorological conditions, air quality monitoring data) or/and open source databases (transport, geographical data) [7]. Modelling results were calibrated to the pollution monitoring data $[87,88]$. The resulting $\mathrm{PM}_{10}$ concentrations can be seen in Supplementary Materials Table S1.

\section{Results}

The complete information on concentrations of each element determined at each sampling site is available in Supplementary Materials Table S1; synoptic data are shown in Table 1. Respecting the fact that the arithmetic mean should not be directly applied to compositional data because it relies on Euclidean geometry and depends on all of the data, including extreme values, and thus not representative of the centre for skewed data [89], the median values are taken for further discussion, and subsequently, the clr-transformed data are used for analyses.

Table 1. Synoptic table of minimum (Min), maximum (Max) value, mean, median, median absolute deviation (MAD), skewness and kurtosis of elements content (ug.g ${ }^{-1}$ ) and (wt.\%) for Al, Fe and N.

\begin{tabular}{|c|c|c|c|c|c|c|c|}
\hline Variable & Min & Mean & Median & Max & MAD & Skewness & Kurtosis \\
\hline June Al & 0.05 & 0.36 & 0.18 & 1.20 & 0.097 & 1.5 & 0.4 \\
\hline October Al & 0.07 & 0.21 & 0.17 & 0.70 & 0.069 & 2.3 & 6.2 \\
\hline June V & 1.4 & 7.7 & 4.7 & 24.1 & 2.6 & 1.3 & 0.3 \\
\hline October V & 2.1 & 6.2 & 5.0 & 19.3 & 2.5 & 1.7 & 2.7 \\
\hline June $\mathrm{Cr}$ & 2.9 & 15.6 & 14.3 & 39.4 & 6.2 & 1.0 & 0.9 \\
\hline October $\mathrm{Cr}$ & 4.1 & 18.9 & 14.8 & 87.4 & 8.9 & 2.8 & 8.9 \\
\hline June Mn & 122.0 & 334.7 & 327.5 & 718.0 & 108.0 & 1.1 & 1.7 \\
\hline October Mn & 93.3 & 320.6 & 259.0 & 843.0 & 58.0 & 1.9 & 4.9 \\
\hline June Fe & 0.12 & 0.70 & 0.70 & 1.20 & 0.423 & -0.1 & -1.8 \\
\hline October Fe & 0.2 & 1.0 & 0.6 & 2.5 & 0.393 & 0.8 & -0.8 \\
\hline June Ni & 2.4 & 6.0 & 4.8 & 13.1 & 1.9 & 1.0 & -0.03 \\
\hline October Ni & 1.9 & 3.5 & 3.3 & 6.5 & 0.9 & 0.9 & -0.01 \\
\hline June Cu & 5.1 & 15.3 & 9.1 & 99.7 & 1.7 & 3.7 & 13.7 \\
\hline October Cu & 4.7 & 7.9 & 7.1 & 16.9 & 1.8 & 1.9 & 5.1 \\
\hline June Zn & 73.4 & 116.7 & 112.5 & 159.0 & 17.5 & 0.1 & -0.5 \\
\hline October Zn & 69.9 & 108.2 & 102.8 & 156.0 & 26.2 & 0.4 & -1.2 \\
\hline June As & $<1.0$ & 2.7 & 0.5 & 14.6 & 0.5 & 1.8 & 2.4 \\
\hline October As & $<1.0$ & 1.0 & & 5.1 & & 1.9 & 2.4 \\
\hline June Cd & 1.0 & 1.5 & 1.4 & 3.0 & 0.33 & 1.7 & 3.0 \\
\hline October Cd & 0.6 & 1.7 & 1.5 & 4.5 & 0.35 & 1.9 & 4.2 \\
\hline June Sb & $<1.0$ & 1.0 & 1.2 & 2.7 & 0.97 & 0.3 & -1.1 \\
\hline June $\mathrm{Hg}$ & 0.041 & 0.075 & 0.074 & 0.108 & 0.016 & 0.01 & -1.2 \\
\hline October $\mathbf{H g}$ & 0.067 & 0.102 & 0.087 & 0.168 & 0.014 & 1.0 & -0.2 \\
\hline June $\mathbf{P b}$ & 4.62 & 19.11 & 12.4 & 70.1 & 4.75 & 2.1 & 4.4 \\
\hline October $\mathbf{P b}$ & 10.8 & 33.2 & 24.85 & 79.8 & 13.05 & 0.9 & -0.5 \\
\hline June N & 1.6 & 2.1 & 2.1 & 2.7 & 0.159 & 0.4 & 1.3 \\
\hline October $\mathbf{N}$ & 1.8 & 2.5 & 2.5 & 3.0 & 0.357 & -0.3 & v1.0 \\
\hline
\end{tabular}




\subsection{Elements Content}

The determined heavy metals and additional elements concentrations were compared with the last Czech state-wide survey $[27,90]$ and data from similar surveys in Spain ( $\mathrm{Zu}$ marraga, Azkoitia) [37] and Turkey (Eregli) [35]—see Table 2. While comparing the data with these studies, it should be noted that the Czech state-wide survey was realised in 2010, the Turkish in 2008 and the Spanish in 2007, and since then, the industrial emission has decreased due to various adopted measures $[4,10]$ (see Figure 2). Moreover, the predominant moss species within the Czech survey were Pleurozium schreberi and Scleropodium purum, while the Spanish and Turkish studies were based on the collection of Hypnum cupressiforme (Hedw.). Though it is supposed that elements concentrations in moss tissue are species-dependent $[56,91,92]$, the information on the interspecies calibration for concerned moss species is still lacking; thus, it could not be performed.

Table 2. Median values of element contents in moss specimens (ug.g ${ }^{-1}$ ) and (wt.\%) for $\mathrm{Al}$, Fe and $\mathrm{N}$ compared to levels reported in relevant studies in Czechia [27,90], Spain (Zumarraga, Azkoitia) and Turkey (Eregli) [35].

\begin{tabular}{|c|c|c|c|c|c|c|c|c|c|c|c|c|c|c|}
\hline Variable & Al & V & $\mathrm{Cr}$ & Mn & $\mathrm{Fe}$ & $\mathbf{N i}$ & $\mathrm{Cu}$ & $\mathrm{Zn}$ & As & $\mathrm{Cd}$ & $\mathrm{Sb}$ & $\mathrm{Hg}$ & $\mathrm{Pb}$ & $\mathbf{N}$ \\
\hline $\begin{array}{l}\text { Třinec } \\
\text { June }\end{array}$ & 1770 & 4.70 & 14.3 & 328 & 6960 & 4.8 & 9.1 & 112.5 & 0.50 & 1.4 & 1.2 & 0.074 & 12.4 & 20,872 \\
\hline $\begin{array}{l}\text { Třinec } \\
\text { Oct. }\end{array}$ & 1730 & 5.00 & 14.8 & 259 & 6330 & 3.3 & 7.1 & 102.8 & & 1.5 & & 0.087 & 24.9 & 25,110 \\
\hline $\begin{array}{c}\text { Czechia } \\
\text { [90] }\end{array}$ & 440 & 1.18 & 1.0 & 449 & 349 & 1.2 & 5.9 & 33.9 & 0.26 & 0.18 & 0.1 & 0.041 & 2.9 & 11,822 \\
\hline $\begin{array}{c}\text { Czechia In. } \\
\text { [27] }\end{array}$ & & 2.18 & 1.8 & & 589 & 1.6 & 6.2 & 37.7 & 0.42 & 0.20 & & 0.055 & 3.9 & 15,667 \\
\hline $\begin{array}{c}\text { Zumarraga } \\
{[37]}\end{array}$ & & 7.90 & 26.1 & & & 8.0 & 33.1 & 304.0 & 1.00 & 0.82 & & 0.13 & 86.0 & \\
\hline $\begin{array}{c}\text { Azkoitia } \\
\text { [37] }\end{array}$ & & 4.99 & 13.7 & & & 14.9 & 17.7 & 250.0 & 1.25 & 0.41 & & 0.07 & 40.7 & \\
\hline $\begin{array}{c}\text { Eregli }^{\mathbf{1}} \\
\text { [35] }\end{array}$ & & & 5.1 & & 3361 & 5.0 & 3.8 & & 0.90 & & & & 24.4 & \\
\hline
\end{tabular}

${ }^{1}$ Hypnum cupressiforme.

The comparison presented in Table 2 shows that levels of all elements recorded in Trrinec were significantly higher in both June and October than in the Czech state-wide data, with the exception of $\mathrm{Mn}$. The most important difference was in the case of $\mathrm{Cr}, \mathrm{Sb}$ (June) and $\mathrm{Cd}$ (an order of magnitude difference), and subsequently, it decreased in the order $\mathrm{Ni}$ $>\mathrm{Al}>\mathrm{V}>\mathrm{Zn}>\mathrm{Fe}>\mathrm{As}>\mathrm{Hg}>\mathrm{Cu}$. Increased concentrations of the listed elements were also stated for the region in previous biomonitoring studies [93,94]. The median value of elements concentration decreased across the sampling area in the order $\mathrm{Fe}>\mathrm{Al}>\mathrm{Mn}>$ $\mathrm{Zn}>\mathrm{Cr}>\mathrm{Pb}>\mathrm{Cu}>\mathrm{Ni}>\mathrm{V}>\mathrm{Cd}>\mathrm{Sb}>$ As and $\mathrm{Hg}$ in June and $\mathrm{Fe}>\mathrm{Al}>\mathrm{Mn}>\mathrm{Zn}>\mathrm{Pb}$ $>\mathrm{C}>\mathrm{Cu}>\mathrm{V}>\mathrm{Ni}>\mathrm{Cd}$ and $\mathrm{Hg}$ in October. Within the Czech state-wide survey, it was $\mathrm{Fe}>\mathrm{Mn}>\mathrm{Al}>\mathrm{Zn}>\mathrm{Cu}>\mathrm{Pb}>\mathrm{V}>\mathrm{Ni}>\mathrm{Cr}>\mathrm{As}>\mathrm{Cd}>\mathrm{Sb}$ and Hg. On the other hand, the medians in Trrinec do not reach the values of the Spanish study (except for Hg). The concentrations of $\mathrm{Fe}, \mathrm{Cr}$ and $\mathrm{Cu}$ in Třinec are about twice higher than the concentrations recorded in Turkey; those of $\mathrm{Ni}$ and $\mathrm{Pb}$ are rather comparable.

From Table 2, it is also apparent that June concentrations across the area were higher in the case of $\mathrm{Al}, \mathrm{Mn}, \mathrm{Fe}, \mathrm{Ni}, \mathrm{Cu}, \mathrm{Zn}, \mathrm{As}$ and $\mathrm{Sb}$; October concentrations were higher for $\mathrm{V}$, $\mathrm{Cr}, \mathrm{Cd}, \mathrm{Hg}, \mathrm{Pb}$ and $\mathrm{N}$. This can be attributed to wet deposition as snowfalls in the area are acidic, thus increasing the accessibility of metals for plants, and to the different emission load related to heating during the winter season.

\subsection{Elements Correlations}

While studying the relationship of the respective elements (transformed data), a significant correlation was revealed between $\mathrm{Al}, \mathrm{V}, \mathrm{Cr}$ (June) and As, the first three representing lithophile elements [95]. Though it can be noted that the concentrations of these elements 
are increased in June samples collected from the ground (TR1-11/13/21), the same relationship was observed in both seasons. Another significant correlation presented in both samplings is between $\mathrm{Zn}$ and $\mathrm{Cd}$ (chalcophile elements) [96]. These are also negatively correlated to the previous group of $\mathrm{Al}$ (June), $\mathrm{V}, \mathrm{Cr}$ and As. It can imply that they are deposited and/or absorb differently and, thus, originate in different sources.

Additionally, a moderate correlation was found between As and Fe (both months), $\mathrm{Cr}$ and $\mathrm{Fe}$ (October) and $\mathrm{Cd}, \mathrm{Hg}$ and $\mathrm{Zn}$ (June). Nitrogen was significantly correlated with $\mathrm{Zn}, \mathrm{Cd}$ and $\mathrm{Hg}$ in June and $\mathrm{Zn}$ and $\mathrm{Hg}$ in October (also stated in [37]). This indicates that the nitrogen pollution in the area can be associated with industrial sources, influenced by combustion during winter $(\mathrm{Cd})$ [97]. For a more detailed relationship assessment, see Figure 5.

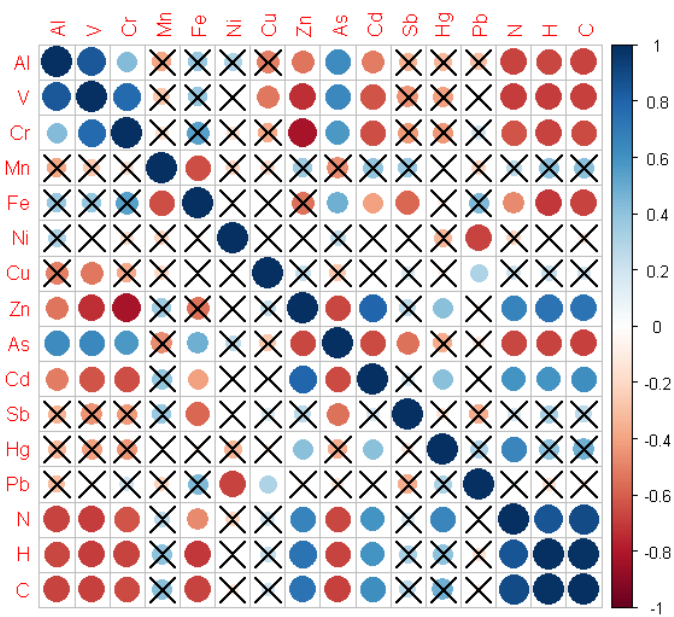

(a)

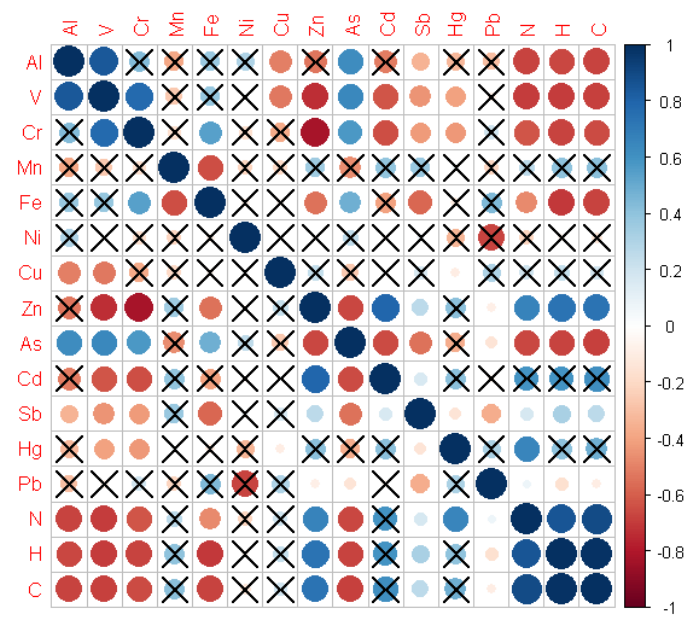

(b)

Figure 5. Correlation plot June (a) and October (b). Size of the point indicates the strength of the correlation, blue- - positive, red-negative correlation; crossed points indicate non-significant correlations.

\subsection{Spatial Distribution of Elements}

The highest concentrations were recorded in the sampling points closest to the factory for $\mathrm{Fe}, \mathrm{Cr}, \mathrm{Cu}, \mathrm{Hg}$ and $\mathrm{Pb}$ in the SE direction (downwind) and in October. See Figure 6 and in Appendix A: Figure A1. A clear decreasing concentration gradient in both prevailing wind directions (SE, NW) with increasing distance from the factory was detected for $\mathrm{Al}$, $\mathrm{As}, \mathrm{Cr}, \mathrm{Cu}, \mathrm{Fe}, \mathrm{Hg}, \mathrm{Pb}, \mathrm{V}$ and $\mathrm{N}$. Moreover, it seems that the correlation of $\mathrm{Al}, \mathrm{As}$ and $\mathrm{V}$ is reflected in their spatial distribution (compare Figure 5 with Figures 6 and A1). The elements concentrations were affected by sampling from the ground (TR1-11/13/21), and we suppose that the gradient disruption in June can be connected to the contamination of samples by soil particles. An unclear or increasing gradient was recorded for $\mathrm{Mn}$, $\mathrm{Zn}, \mathrm{Cd}$ and $\mathrm{Ni}$ (similarly as in [43]); $\mathrm{Zn}$ and $\mathrm{Cd}$ had a comparable spatial distribution which reflected the correlation once again (Figure 5). Though Mn is present in emissions of steelmaking processes in significant amounts, the spatial behaviour of Mn stays unclear and the steelmaking-associated gradient was not confirmed by biomonitoring so far $[33,35,39,90,98]$. This can be connected to the solubility and mobility of $\mathrm{Mn}$. $\mathrm{Mn}$ is in the form best accessible to plants while in an acid environment with low redox potential, and therefore its intake is significantly higher in spring and coniferous woods, which can explain its variance in surroundings. 

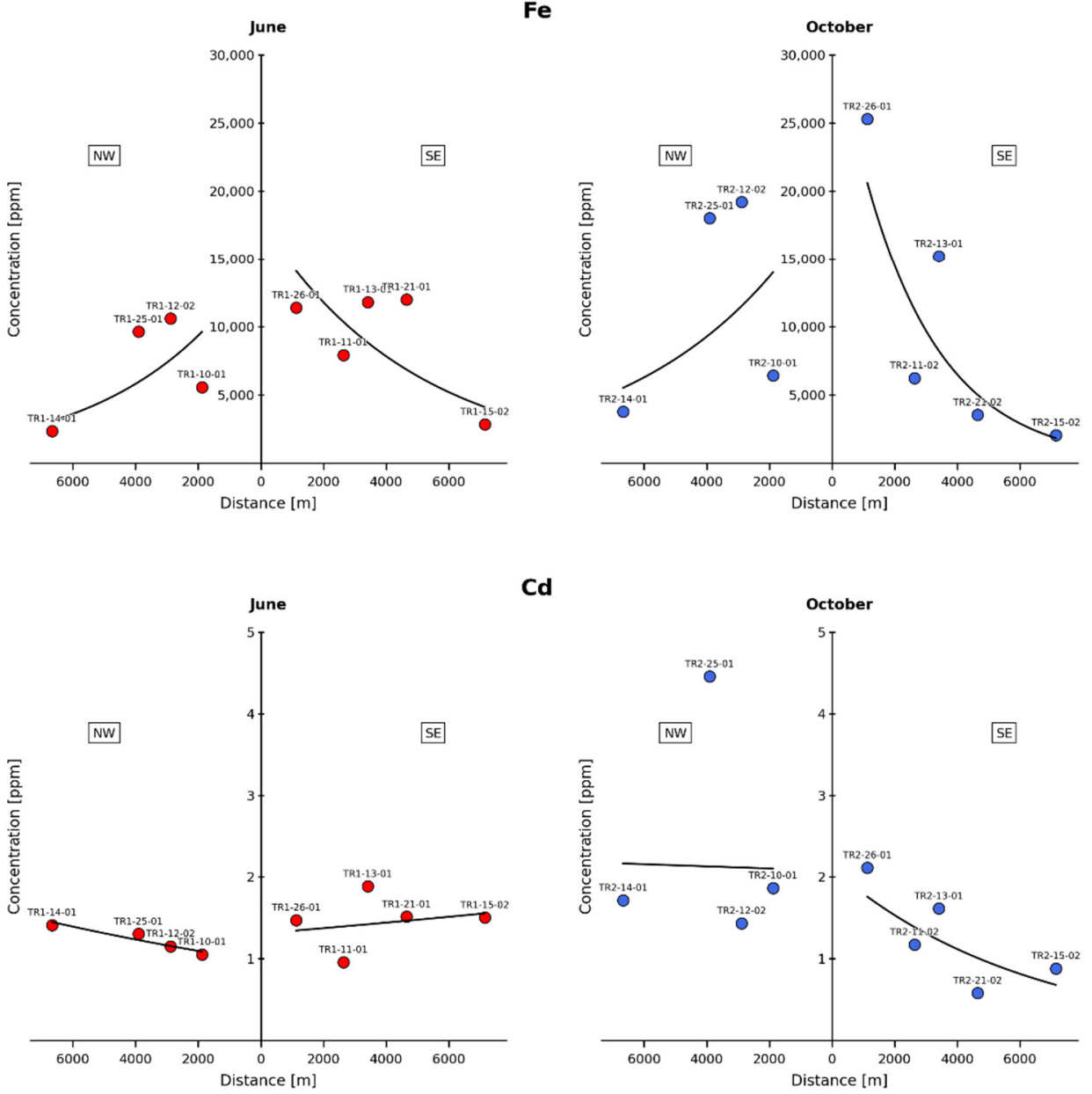

Cd
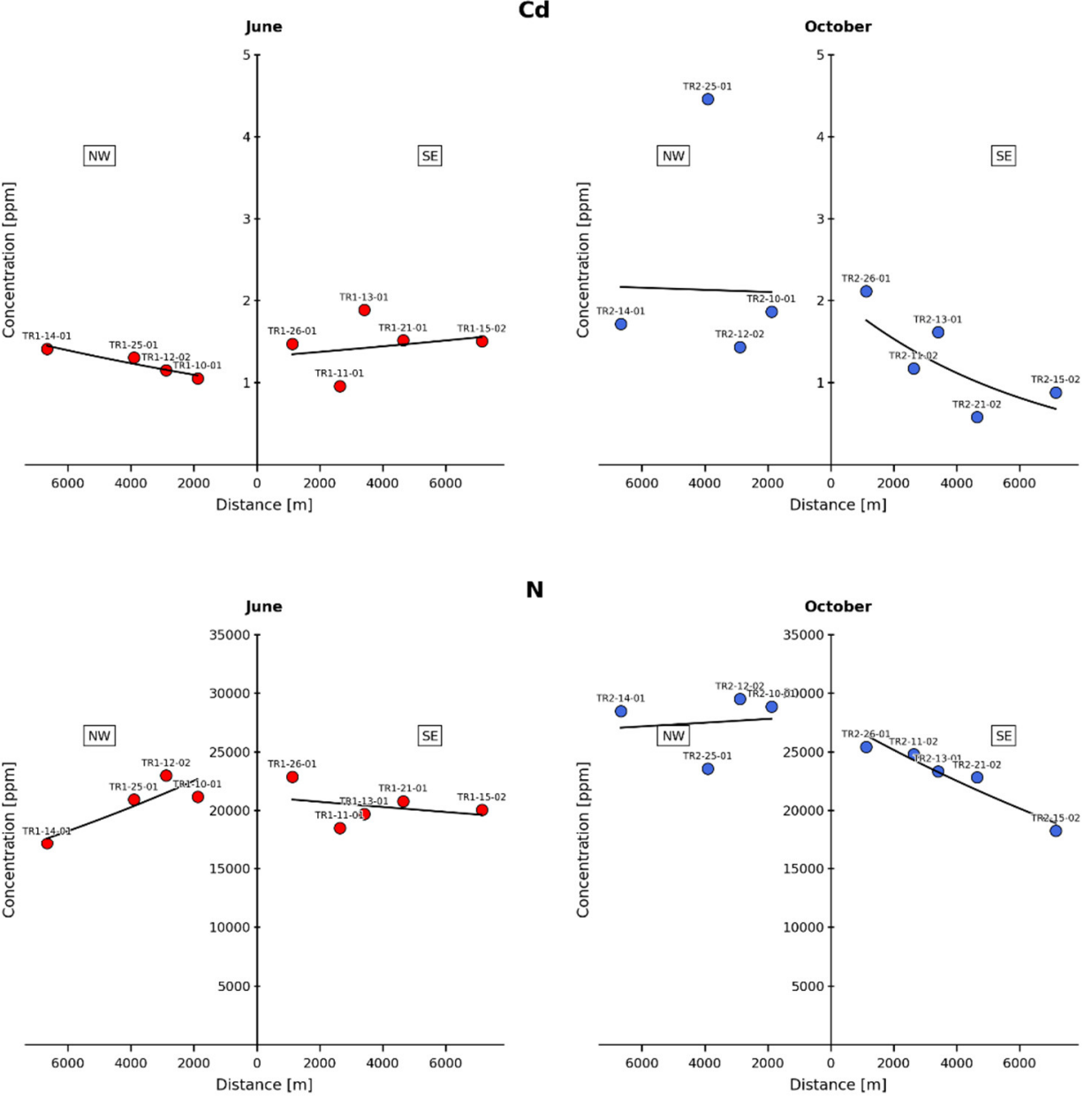

Figure 6. Gradients of concentrations of the assessed elements in terrestrial mosses collected in the surroundings of the Třinec Iron and Steel Works.

Moreover, $\mathrm{Zn}, \mathrm{Cd}$ and $\mathrm{Ni}$ are pollutants inevitably present in emissions from both primary and secondary metallurgy carried by fine particles $\left(<\mathrm{PM}_{2.5}\right)[12,14,99]$. Consequently, they are significantly more influenced by the immediate atmospheric dispersion situations and, thus, by different meteorological conditions in winter (not only wind speed and direction). Gradient charts of these elements in Figures 6 and A1 (in Appendix A) show that following the summer (in October), the downwind decreasing gradient is more evident, considerably in the case of Ni. This can also refer to the fact that more pollution sources are emitting these elements in winter. 
The sampling design also covered two leeward sites (N, SSW direction) and three sites on the hillside (SSW direction) expected to be affected by the factory minimally (Figure 4). However, this assumption was confirmed only for the sampling sites at the Javorový hill (except for concentrations of $\mathrm{Mn}$, which were already discussed above). The results showed that the site on the north was directly influenced by sintering processes (highest concentrations of $\mathrm{Pb}$ and $\mathrm{Cu}$ ), while the site on the south by the slug dump (highest concentrations of $\mathrm{Mn}$ and $\mathrm{Cr}$ ).

\subsection{Principal Component Analysis (PCA)}

The relations among elements in collected moss, sampling season, modelled PM and site orientation were further investigated using PCA. According to the results, the first two dimensions express $63.07 \%$ of the total inertia, which is a significantly greater amount of inertia than the reference value of $32.89 \%$ obtained by the 0.95 -quantile of inertia percentages distribution (simulation of 940 normal-distribution data tables of similar size). Thus, the description is focused on the first two dimensions. Individual sampling sites orientation in the first factor plane is presented in Figure 7 together with the supplementary qualitative variables and distance from the predominant source. The correlation circle of the active quantitative variables is presented in Figure 8.

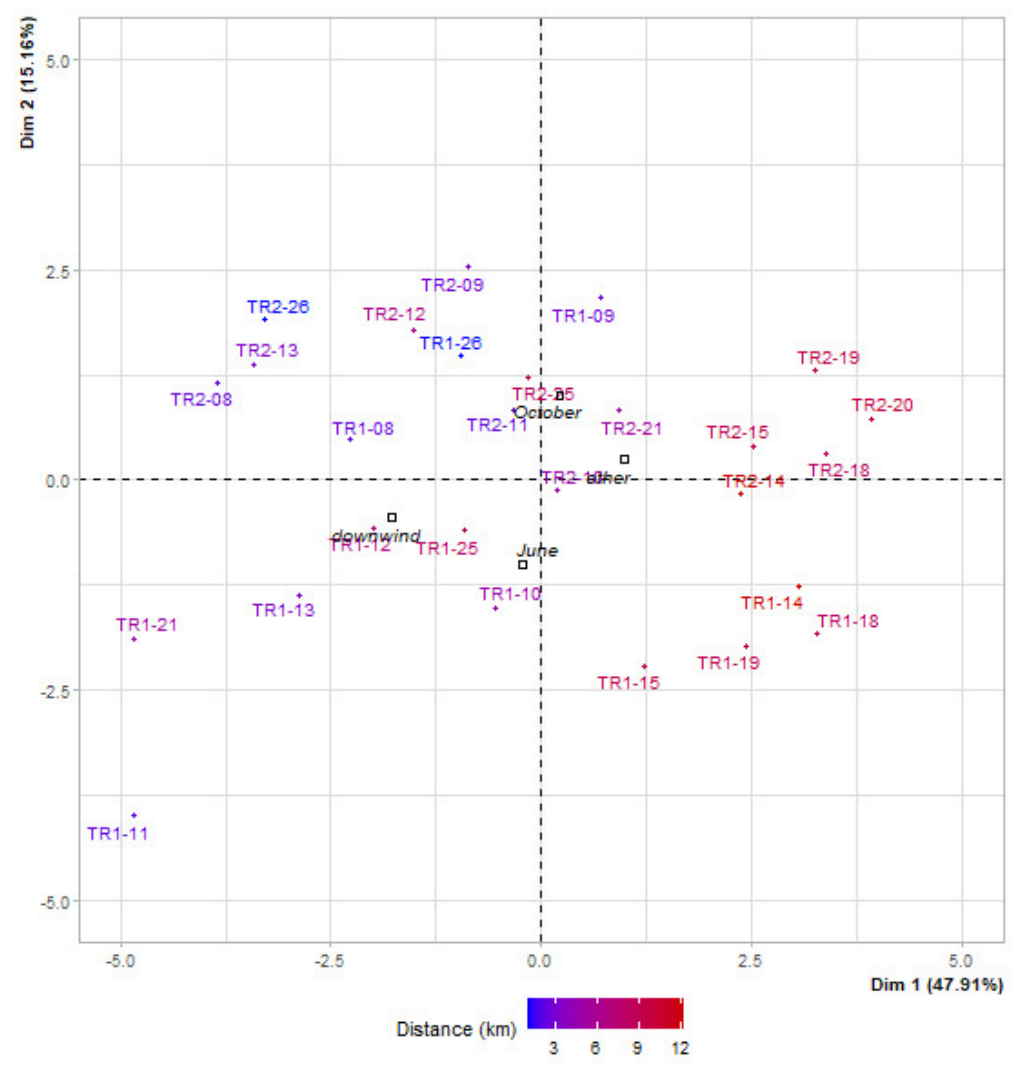

Figure 7. PCA results, first factor plane. Season, prevailing wind relative to the factory and distance from the factory are plotted as supplementary variables. 


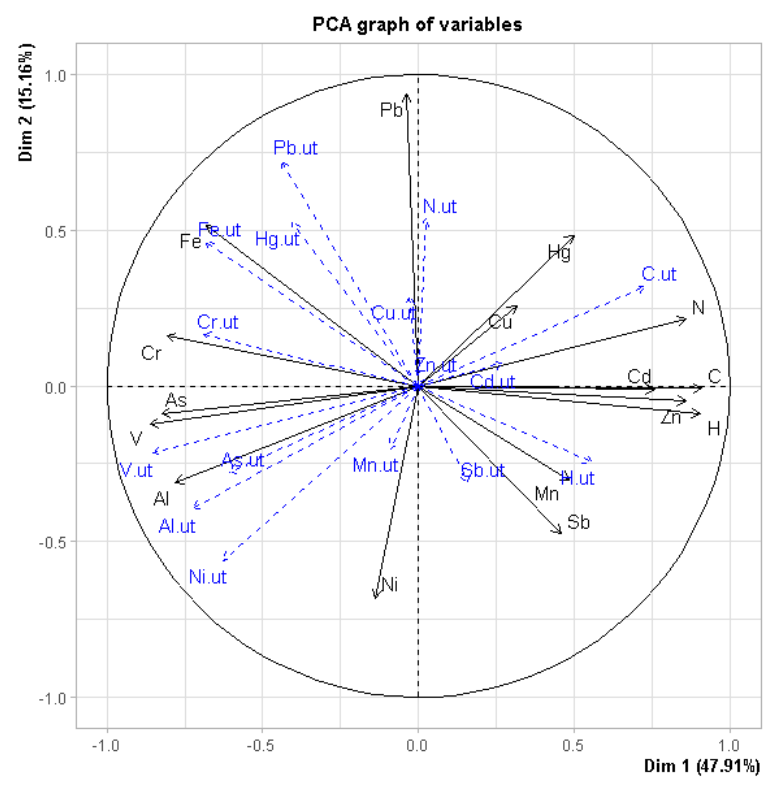

Figure 8. PCA results, first factor plane. Correlation circle of the (clr-transformed) concentrations of elements (in black) and untransformed data (in blue).

The first dimension is positively correlated with the clr-transformed concentrations of $\mathrm{C}(\mathrm{r}=0.91), \mathrm{H}(\mathrm{r}=0.91), \mathrm{N}(\mathrm{r}=0.86), \mathrm{Zn}(\mathrm{r}=0.86), \mathrm{Cd}(\mathrm{r}=0.76)$ and one quantitative supplementary variable-distance from the factory $(r=0.74)$. It is negatively correlated with clr-transformed concentrations of $\mathrm{V}(\mathrm{r}=-0.86)$, As $(\mathrm{r}=-0.82), \mathrm{Cr}(\mathrm{r}=-0.81), \mathrm{Al}(\mathrm{r}=-0.78)$, $\mathrm{Fe}(\mathrm{r}=-0.68)$ and two quantitative supplementary variables-modelled concentrations of $\mathrm{PM}_{10}$ in winter $(\mathrm{r}=-0.58)$ and modelled concentrations of $\mathrm{PM}_{10}$ in summer $(\mathrm{R}=-0.55)$. Wilks test also indicates association of the axis with wind direction $(p=0.018)$, with the sites downwind tending to have negative scores on this axis while those not downwind tending to have positive scores.

This suggests that the first dimension grouped elements exhibiting a spatial gradient with decreasing PM concentration and increasing distance from the factory $(\mathrm{V}, \mathrm{As}, \mathrm{Cr}$, $\mathrm{Al}, \mathrm{Fe}$ - — negative correlation, and those with opposite spatial distribution $(\mathrm{Zn}, \mathrm{Cd}, \mathrm{N})$ with positive correlation. Pollutants in the respective groups also most likely originate in a different type of source. While the negatively correlated group of elements suggests metallurgical processes, the opposing group seems to be associated with coal combustion [99-102]. A positive correlation of $\mathrm{C}$ and $\mathrm{H}$ in this group can indicate the change of the environment with increasing distance from the source toward a more natural landscape and thus more favourable conditions for growing.

The second dimension is positively correlated with the clr-transformed concentrations of $\mathrm{Pb}(\mathrm{r}=0.93)$, and, to a lesser extent, $\mathrm{Fe}(\mathrm{r}=0.51)$ and $\mathrm{Hg}(\mathrm{r}=0.48)$ while negatively correlated with clr-transformed concentrations of $\mathrm{Ni}(\mathrm{r}=-0.68)$ and $\mathrm{Sb}(\mathrm{r}=-0.56)$. Wilks test result indicates a strong association of the axis with the season $(p=0.001)$, with the October samplings having positive scores on the axis and those sampled in June having negative scores.

The second dimension grouped elements with a strong association to the season- $\mathrm{Pb}$ and $\mathrm{Ni}$-suggesting, once again, a different origin of pollution; probably sintering for the positively correlated elements and steelmaking for negatively correlated ones [99-101].

Original, untransformed, concentration data of selected elements were plotted over the PCA results to illustrate their relationship to the two first dimensions and, thus, to wind and distance from the factory — associated with the first axis—and season—associated with the second axis (Figure 9). The only elements correlated with the first axis alongside the gradient of distance (positive correlation) were $C(r=0.75)$ and $H(r=0.73)$, which tended to have higher concentrations in samples the furthest from the predominant source. Negatively correlated were concentrations of $\mathrm{V}(\mathrm{r}=-0.85), \mathrm{Al}(\mathrm{r}=-0.72), \mathrm{Cr}(\mathrm{r}=-0.69)$, 
$\mathrm{Fe}(\mathrm{r}=-0.68)$, $\mathrm{Ni}(\mathrm{r}=-0.63)$, As $(\mathrm{r}=-0.61), \mathrm{Pb}(\mathrm{r}=-0.44)$ and $\mathrm{Hg}(\mathrm{r}=-0.41)$; concentrations of these element tended to decrease downwind with increasing distance to the factory.

Al

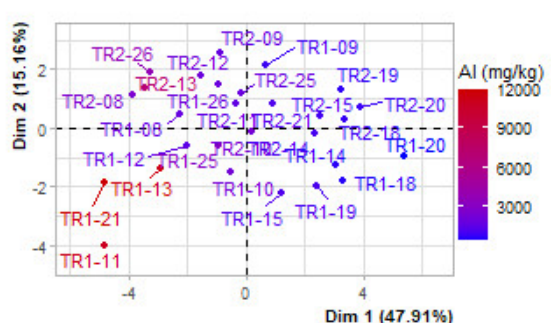

Cd

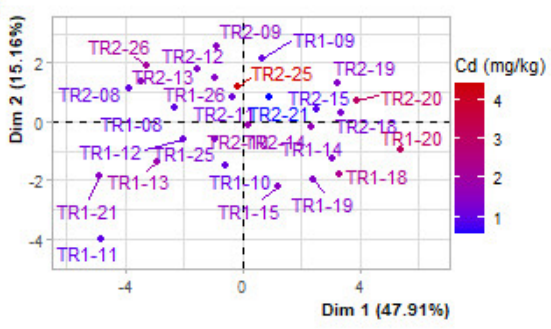

$\mathrm{Cu}$

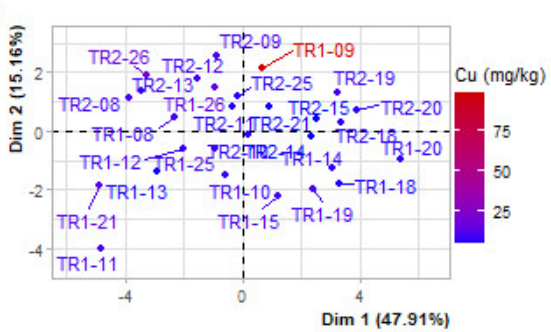

$\mathrm{Mn}$

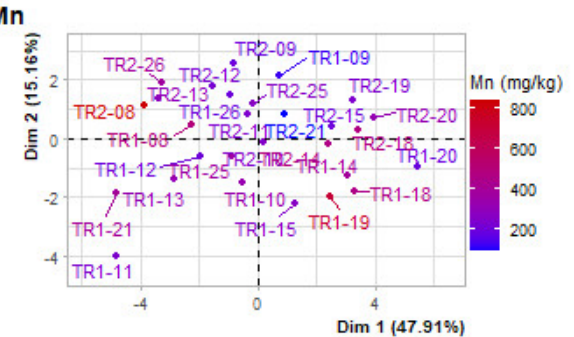

$\mathrm{Ni}$
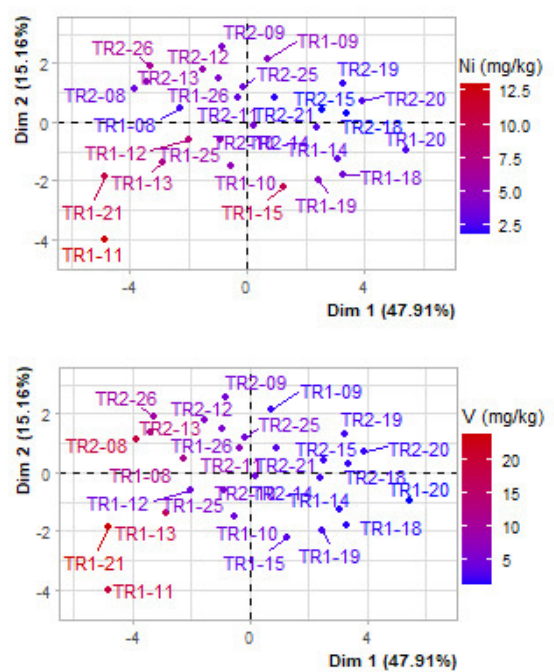

As

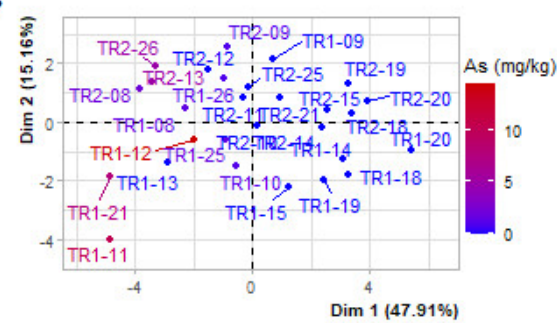

$\mathrm{Cr}$

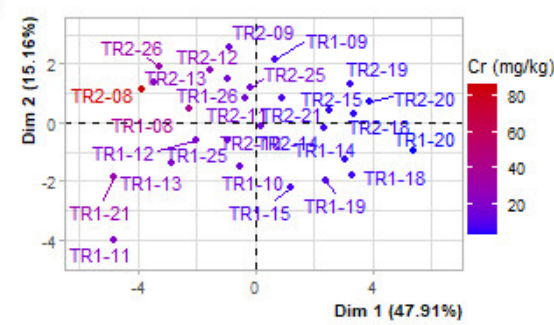

$\mathrm{Hg}$

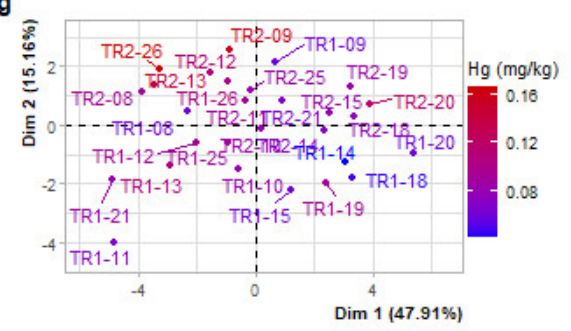

N

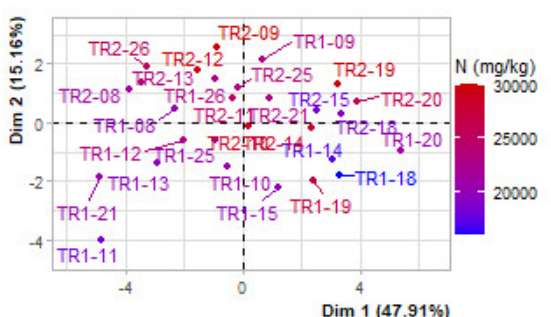

$\mathrm{Pb}$

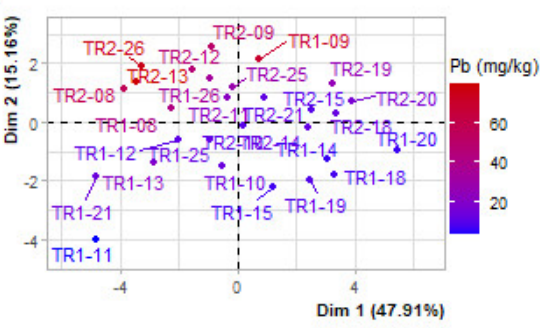

$\mathrm{Zn}$

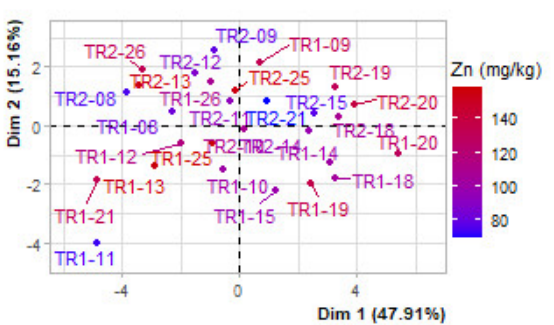

Figure 9. Untransformed concentrations of selected elements plotted over the PCA results. 
Elements associated with the second axis characterized by the factor of season were $\mathrm{Pb}(\mathrm{r}=0.72), \mathrm{N}(\mathrm{r}=0.54), \mathrm{Hg}(\mathrm{r}=0.53)$ and $\mathrm{Fe}(\mathrm{r}=0.46)$ which were correlated positively and $\mathrm{Ni}(\mathrm{r}=-0.56)$ and $\mathrm{Al}(\mathrm{r}=-0.40)$ showing negative correlation to the axis. The positively correlated elements were found in higher concentrations in the moss material sampled in October, while those sampled in June tended to have higher concentrations of the negatively correlated elements.

\subsection{Hierarchical Clustering on Principal Components}

For better understanding similarities in collected biomonitoring data, hierarchical clustering was used to identify respective groups of corresponding sites. Hierarchical Clustering on Principal Component (HCPC) performed on the results of the June sample collections (clr-transformed concentrations) revealed four clusters of sampling sites which were plotted in the map (Figure 10a). Cluster 1 was characterised by higher values of $\mathrm{Al}$ and $\mathrm{V}$ and lower values of $\mathrm{H}, \mathrm{C}$ and $\mathrm{N}$ in comparison to the dataset means. Cluster 2 was not distinct by any lower or higher values. Cluster 3 was distinct by higher $\mathrm{H}, \mathrm{N}$, $\mathrm{Mn}, \mathrm{Zn}, \mathrm{Cd}$ and $\mathrm{C}$ values while having lower values of Fe, Cr, V, As and Al. Cluster 3 was characterised by higher values of $\mathrm{Pb}$ and $\mathrm{Cu}$. According to the characterisation and location of respective sites, it can be assumed that Cluster 1 gathered sites influenced by soil particles; Cluster 2 sites had dominant pollution from the factory; the site representing Cluster 3 was directly affected by sintering plant, and the last cluster comprised sites in a more natural environment with a lower impact of the factory.

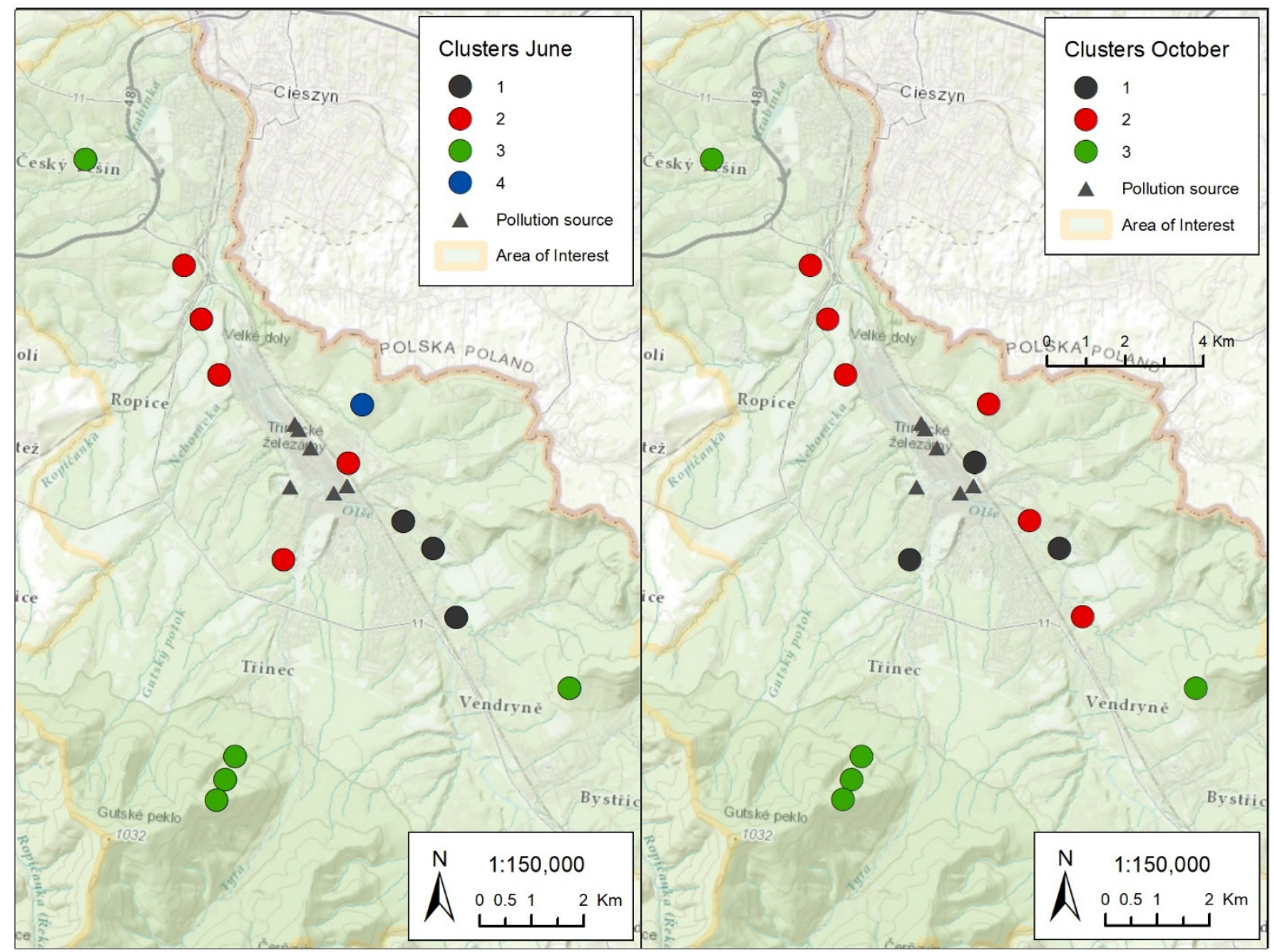

(a)

(b)

Figure 10. Clusters resulting from HCPC: (a) June sampling, (b) October sampling. 
In the case of October samplings, HCPC revealed three clusters (Figure 10b). Cluster 1 was characterised by higher values of $\mathrm{As}, \mathrm{Al}, \mathrm{V}, \mathrm{Pb}$ and $\mathrm{Cr}$ and lower values of $\mathrm{C}, \mathrm{H}, \mathrm{N}, \mathrm{Sb}$ and $\mathrm{Zn}$. Cluster 2 was distinct only by the lower values of $\mathrm{Mn}$, while Cluster 3 was distinct by higher values of $\mathrm{C}, \mathrm{Sb}, \mathrm{Zn}, \mathrm{H}, \mathrm{Mn}$ and $\mathrm{N}$ and lower values of $\mathrm{Fe}, \mathrm{Al}, \mathrm{V}, \mathrm{Cr}$ and $\mathrm{As}$. The clustering of sampling point in October can suggest the similar origin of the pollution for Clusters 2 and 3 as in June, except that Cluster 2 comprises the site of June Cluster 4. Samples grouped in Cluster 1 for this season had no direct connection to possible soil contamination and thus also represented the pollution from the factory.

Visualisation of the correlation matrix of the clr-transformed concentrations of both the June and October samplings are presented in Figure 11a,b, respectively. In both cases, modelled $\mathrm{PM}_{10}$ concentrations of the previous season (winter for June and summer for October sampling) were also assessed. As is apparent, the modelled $\mathrm{PM}_{10}$ concentrations were, in both campaigns, closely positively correlated with recorded Fe concentrations, and in the case of the October sampling with the concentrations of As. This confirms Fe as the strongest biomonitoring marker for assessing the impact of metallurgical processes on the environment as it is predominantly carried by the coarse particles and consequently deposited closer to the facility $[23,25,27,28,30]$. On the other hand, a significant negative correlation was found for $\mathrm{Mn}$ and $\mathrm{Cd}$ concentrations in the case of June samplings, while in the October samplings, the modelled $\mathrm{PM}_{10}$ negatively correlated with the concentrations of $\mathrm{Zn}, \mathrm{C}, \mathrm{H}$ and $\mathrm{N}$. This can suggest that $\mathrm{Mn}, \mathrm{Zn}$ and $\mathrm{Cd}$ are not good markers to study the pollution load in the vicinity of an industrial source as they are carried by fine particles and their spatial distribution depends more on atmospheric dispersion and long-range transport.

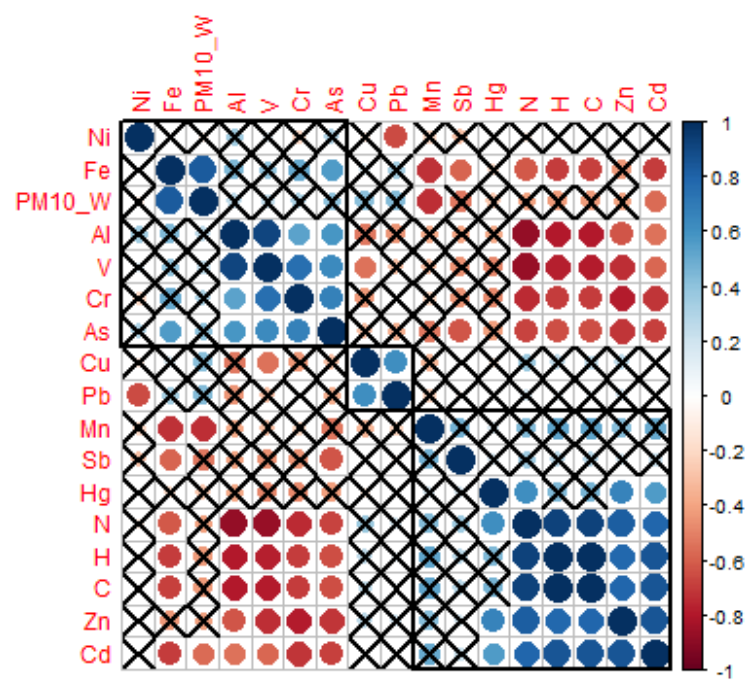

(a)

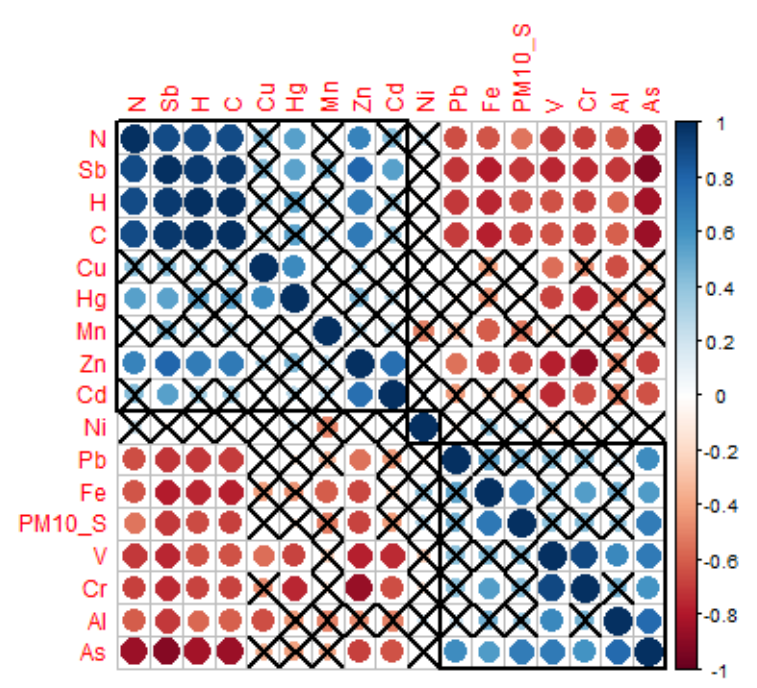

(b)

Figure 11. Correlation plot of June sampling (a) and October sampling (b). Size of the point indicates the strength of the correlation, blue-positive, red-negative correlation; crossed points indicate the non-significant correlations.

\section{Discussion}

The assessed integrated Iron and Steel Works (Třinec, Czechia) meet all the legal requirements and comply with the best available techniques (BAT), which guarantee minimising emissions and adverse impacts on the environment [11]. However, the analysed samples of Brachythecium rutabulum (Hedw.) in the surroundings of the factory revealed significantly elevated concentrations of all studied elements (except for $\mathrm{Mn}$ ) in comparison to the last Czech state-wide survey in 2010. The observed difference ratio decreased in the order $\mathrm{Cr}>\mathrm{Sb}>\mathrm{Cd}>\mathrm{Ni}>\mathrm{Al}>\mathrm{V}>\mathrm{Zn}>\mathrm{Fe}>\mathrm{As}>\mathrm{Hg}$ and $\mathrm{Cu}$, while the first three elements reached the order of magnitude difference. 
To prove that the elevated concentrations of analysed elements are associated with the emissions from the factory, PCA and HCPC were applied. Prior to the investigation, the data were transformed according to the principles of compositional data analysis. While examining the biomonitoring data, this procedure is often omitted, and data are treated in such a way that they are seldom published. Statistical treatment is usually applied directly to the untransformed dataset, ignoring the compositional character of the data and, thus, the relativity of obtained information. Consequently, such results are inappropriately assessed. The approach applied in this study proved the legitimacy of the data transformation and the applicability of compositional data analysis principles to the biomonitoring assessment of a local pollution source.

Thus, concentration gradients relative to the distance from the factory in the prevailing wind directions and the whole area were established, confirming the initial hypothesis of the study. The most significant trends were observed for $\mathrm{V}, \mathrm{As}, \mathrm{Cr}, \mathrm{Al}, \mathrm{Fe}$ (ordered by the significance), while $\mathrm{V}, \mathrm{As}, \mathrm{Al}$ and $\mathrm{Cr}$ (in June) also showed strong correlations to each other. These elements exhibited decreasing concentration with the increasing distance to the factory, significant association to the modelled $\mathrm{PM}_{10}$ concentrations and clear gradient in the prevailing wind directions. The strongest correlation of modelled $\mathrm{PM}_{10}$ concentrations was found with concentrations of Fe for both seasons. These facts point to the emission source in the facility and to the bonding of the metal to relatively coarse particles. An opposite trend was found for $\mathrm{Zn}, \mathrm{Cd}$ and $\mathrm{N}$, which also showed strong mutual correlations.

Further examination implies the association of these pollutants to the fine PM fraction and, thus, a different dispersion mechanism than the previously mentioned group of elements. When investigating the similarity of sampling localities by hierarchical clustering, the same groups of elements were decisive for assigning a site a respective cluster. The clusters connecting the first group of elements comprised the closest sites directly influenced by the source emissions, whereas the cluster connecting the second group included the most distant, outlying sites.

The association of the pollution with the carrying particles (coarse or fine) was demonstrated for the first time in such a study and was possible because of the application of the data transformation. The same statement is relevant for the revelation of the importance of the season chosen for sampling.

Though further analysis showed the significance of the sampling season to the determined concentrations of elements, the most substantial relationship was found for $\mathrm{Pb}, \mathrm{Fe}$ and $\mathrm{Hg}$ (June), and $\mathrm{Ni}$ and $\mathrm{Sb}$ (October); the results suggest that the proper data transformation can compensate this effect to a certain extent. This compensation clearly refers to the bound of the investigated pollutant to the respective PM fraction, and it is the most important factor for the pollution distribution in the area. Still, while assessing an individual pollution source in the climate of Central Europe, it seems more appropriate to perform the biomonitoring following summer to avoid interferences with other pollution sources associated with the heating season.

While assessing the aforementioned facts, the limitations of the case study should be taken into consideration. The studied area is situated in the temperate zone of a continental climate with a long-term tradition of using black coal for heating during the cold part of the year, presenting a specific type of pollution source, which must be embraced in such studies. Moreover, the area has a specific topography (a narrow valley bordered by relatively high mountains) determining particular meteorological conditions (clear prevailing wind directions influenced by anabatic and katabatic winds). Therefore, the studied factory is comparatively isolated from the neighbouring regions, and its pollution dominates over the local emission sources (such as domestic boilers and transport). For further verification of the revealed facts, a more extensive study should be performed, covering analyses of the airborne PM pollution, the distribution of the elements within PM fractions and performed on a more extensive area.

Within the last decade, the Iron and Steel Works in Třinec realised extensive environmental measures and technological improvements, leading to an important reduc- 
tion of emissions (TSP emission decreased by $85 \%$ ). However, this study proved that it is still the most significant pollution source in the area; the emissions from the factory increase levels of heavy metals in its vicinity and have a substantial impact on the surrounding environment.

\section{Conclusions}

Small-scale moss biomonitoring in the vicinity of an industrial source (integrated iron and steelworks) was performed for the first time while following the principles of compositional data analysis (CoDa). The centred-log ratio transformation of the data prior to the multivariate analyses allowed the distinction of elements determined in mosses associated with coarse and fine PM fractions, thus, the applicability of the proper data treatment even in small-scale surveys. Furthermore, the relationship between the modelled $\mathrm{PM}_{10}$ concentrations and the elemental composition of moss samples was also observed for the first time in such a study.

Moreover, the suitability of moss biomonitoring of the single-source industrial pollution even in an enclosed region and short time frame was demonstrated. However, in accordance with the results of this study, sampling following the warm season is hereby encouraged in order to avoid skewing the results due to the influence of other sources connected to heating.

Nevertheless, the applicability of the results of this case study should be assessed by replicating the study in different industrial, geographical and climate settings since the novel aspects of this study prevent a direct comparison at the moment.

Supplementary Materials: The following are available online at https:/ / www.mdpi.com/article/10 .3390/app11178262/s1, Table S1: Complete data on samples—sampling sites description, chemical analyses results and assigned modelled $\mathrm{PM}_{10}$ concentrations.

Author Contributions: Conceptualisation, I.P.; validation, I.P. and O.M.; formal analysis, O.M.; investigation, I.P.; data curation, I.P. and O.M.; resources, I.P., V.P. and J.B.; writing-original draft preparation, I.P., O.M. and V.P.; writing—review and editing, I.P., O.M. and V.P.; visualisation, I.P., O.M. and J.B.; supervision, I.P.; project administration, I.P. All authors have read and agreed to the published version of the manuscript.

Funding: The study was published within the Plenipotentiary grant "Moss Monitoring Study of the Trace Metal Pollution using Neutron Activation Analysis and Inductively Coupled Plasma Atomic Emission Spectroscopy", grant number 11/181; and "Simulated dry deposition of nanomaterials and assessment of its influence on plants using nuclear methods", grant number 16/182 for the cooperation with the Joint Institute for Nuclear Research by Joint Institute for Nuclear Research within the theme No. 03-4-1128-2017/2022 and the "SGS" grant SP2021/44 "Characteristics of the transfer of suspended particles using neutron activation analysis and additional analytical methods, including the use of UAVs and new procedures for the treatment of organic waste".

Institutional Review Board Statement: Not applicable.

Informed Consent Statement: Not applicable.

Data Availability Statement: The data presented in this study are available in the article and Supplementary Materials.

Acknowledgments: We would like to thank the analytical team of the Nanotechnology Centre, CEET, VSB-Technical University of Ostrava, led by Jana Seidlerová for performing chemical analyses on the ICP-AES and AAS. Further, we would like to thank Adrian Pryszcz and the Institute of Environmental Technology for the possibility of performing the elemental analysis. Finally, we would like to thank our friend Kateřina Tomšejová for her help with sampling, sample treatment and performing elemental analysis.

Conflicts of Interest: The authors declare no conflict of interest. The funders had no role in the design of the study; in the collection, analyses or interpretation of data; in the writing of the manuscript or in the decision to publish the results. 


\section{Appendix A}
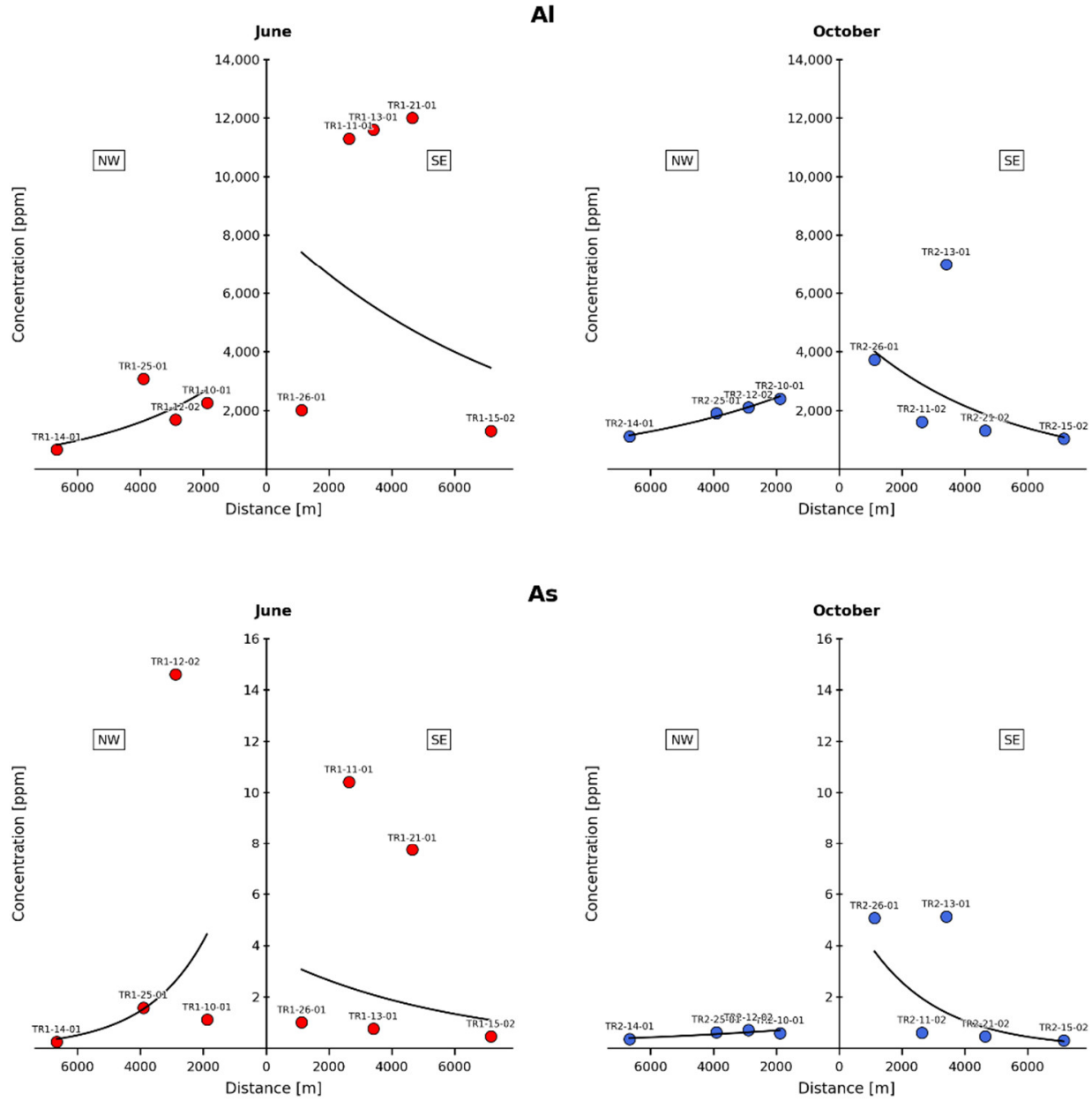

As
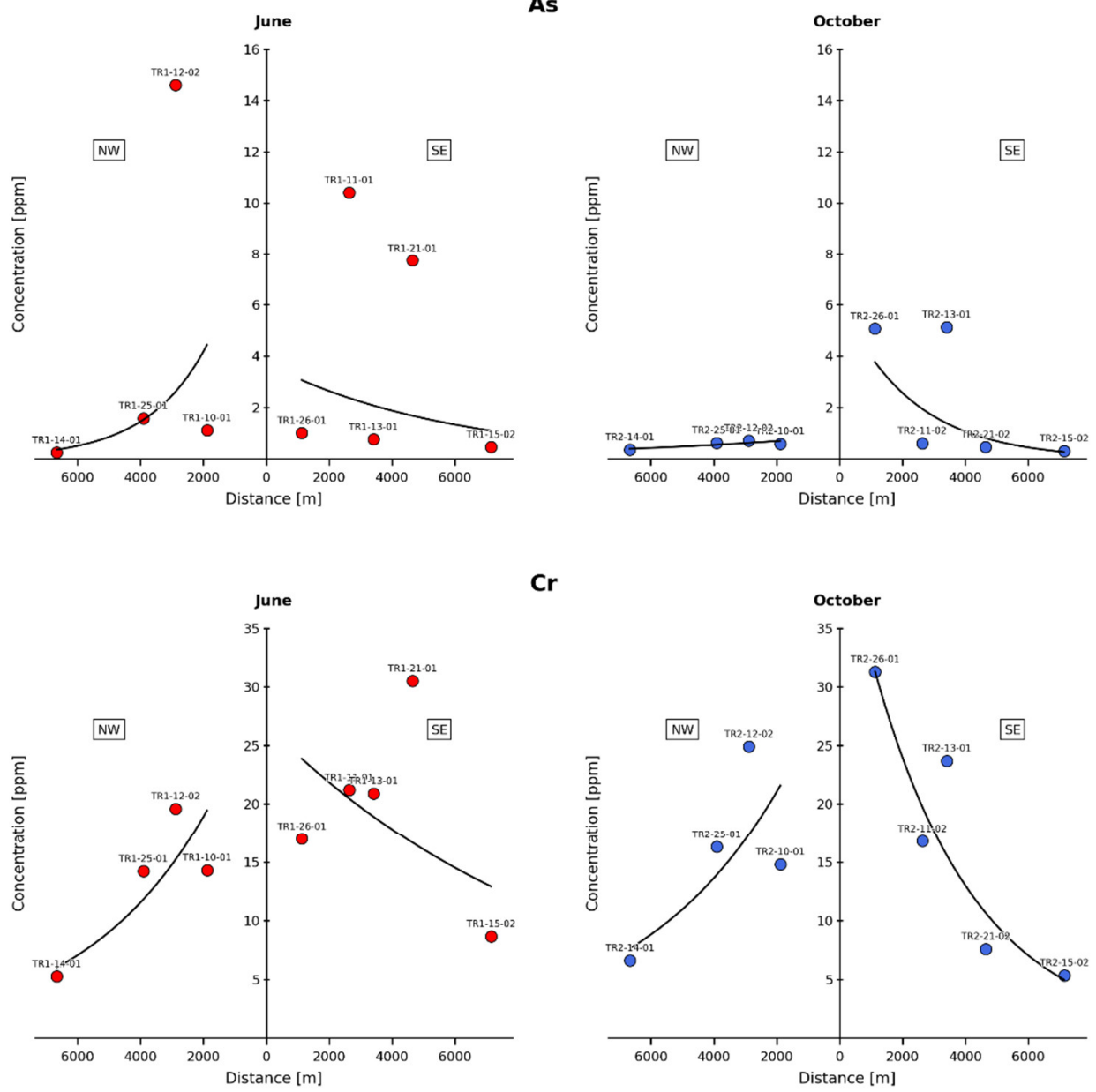

$\mathrm{Cr}$

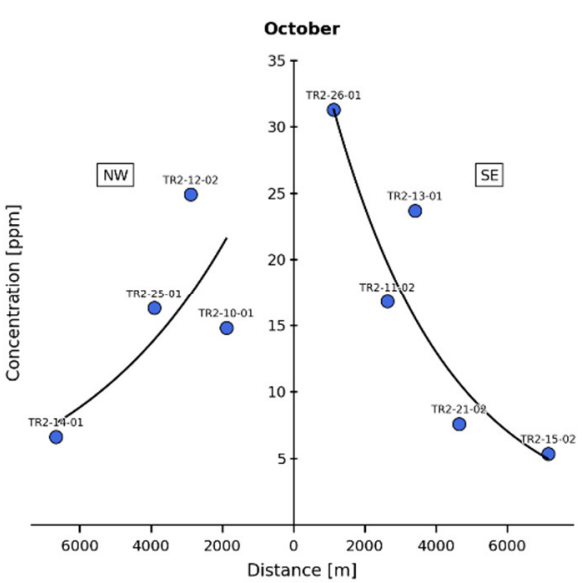

Figure A1. Cont. 


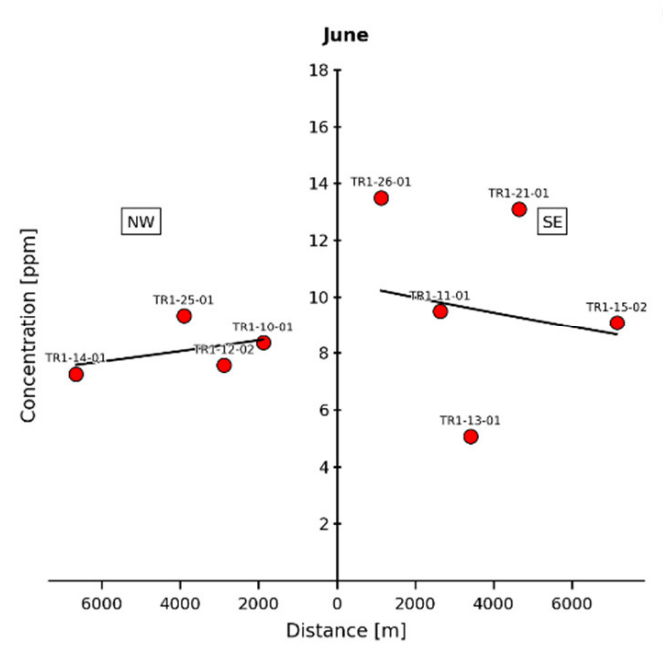

$\mathrm{Cu}$
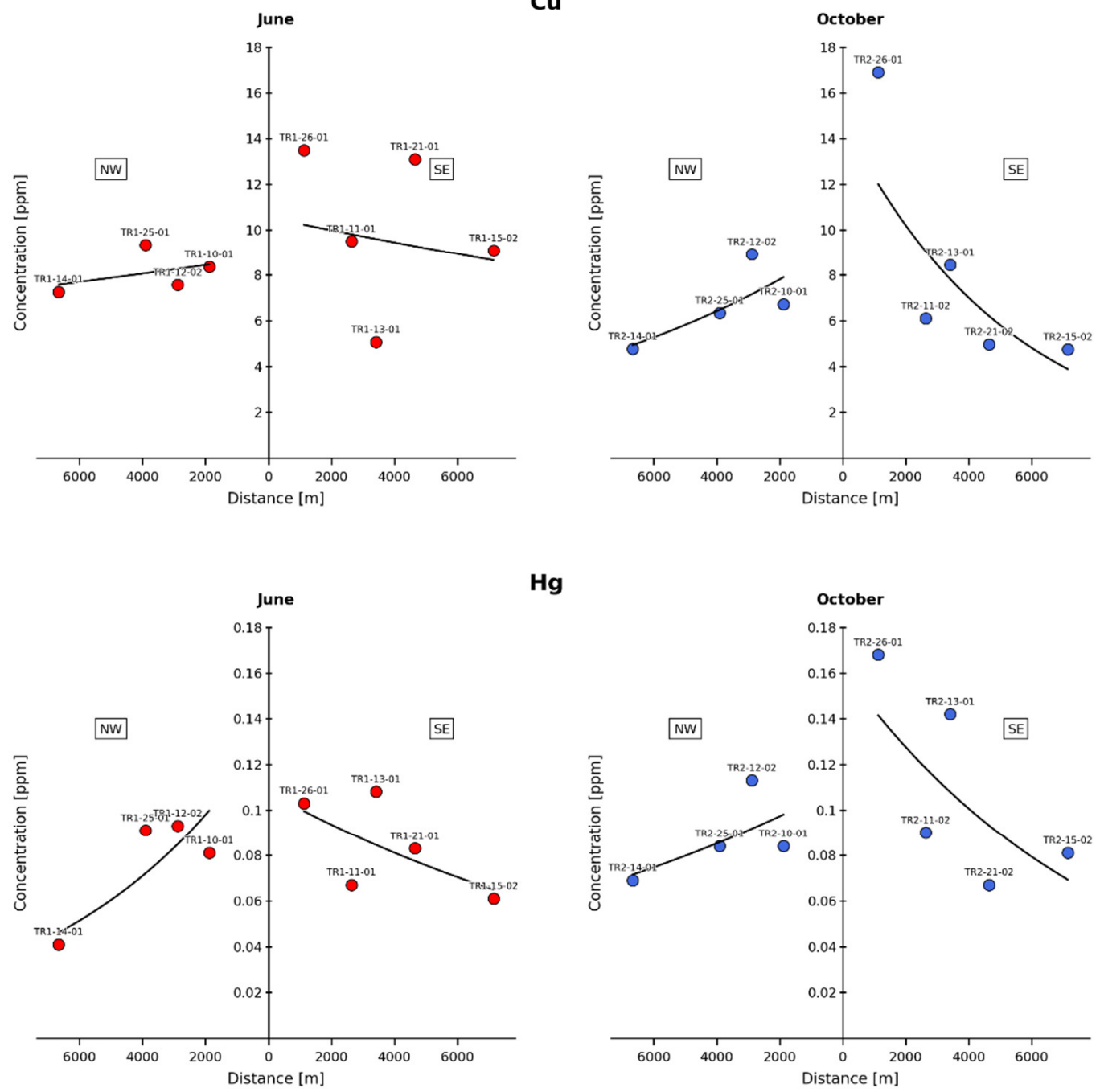

$\mathrm{Hg}$
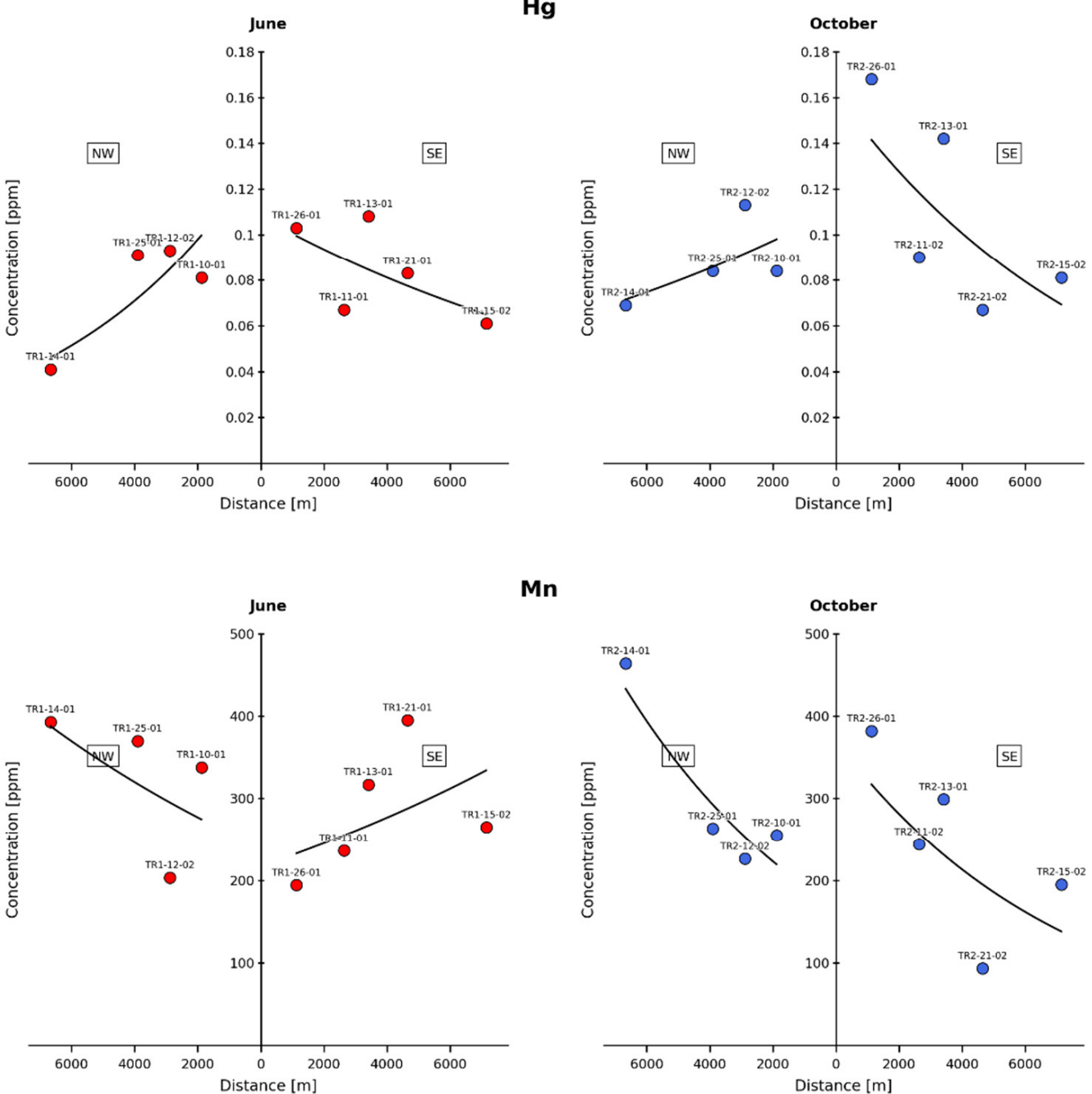

Mn

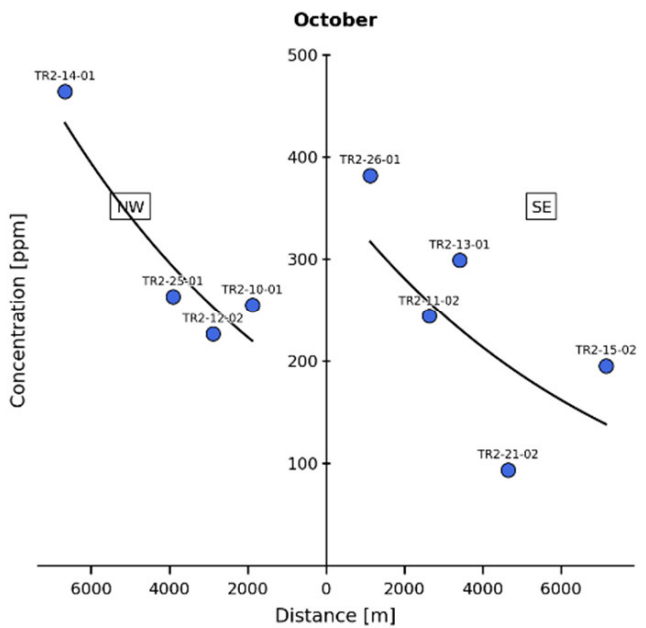

Figure A1. Cont. 


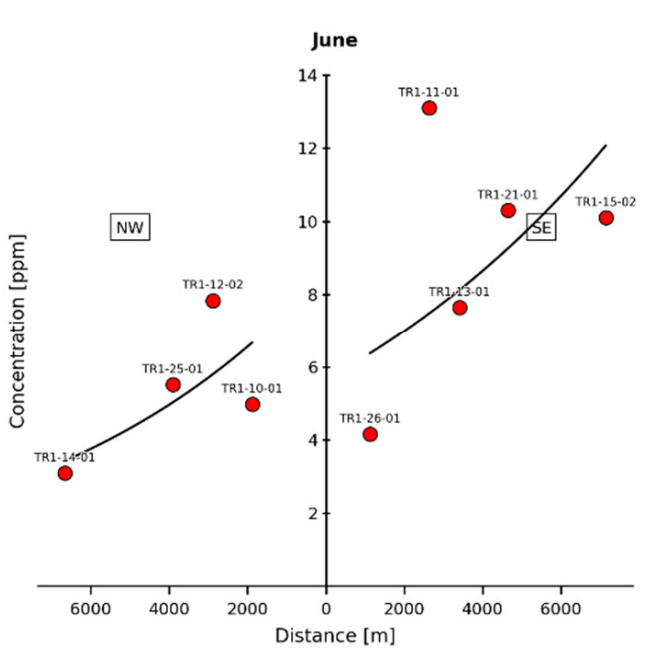

$\mathbf{N i}$
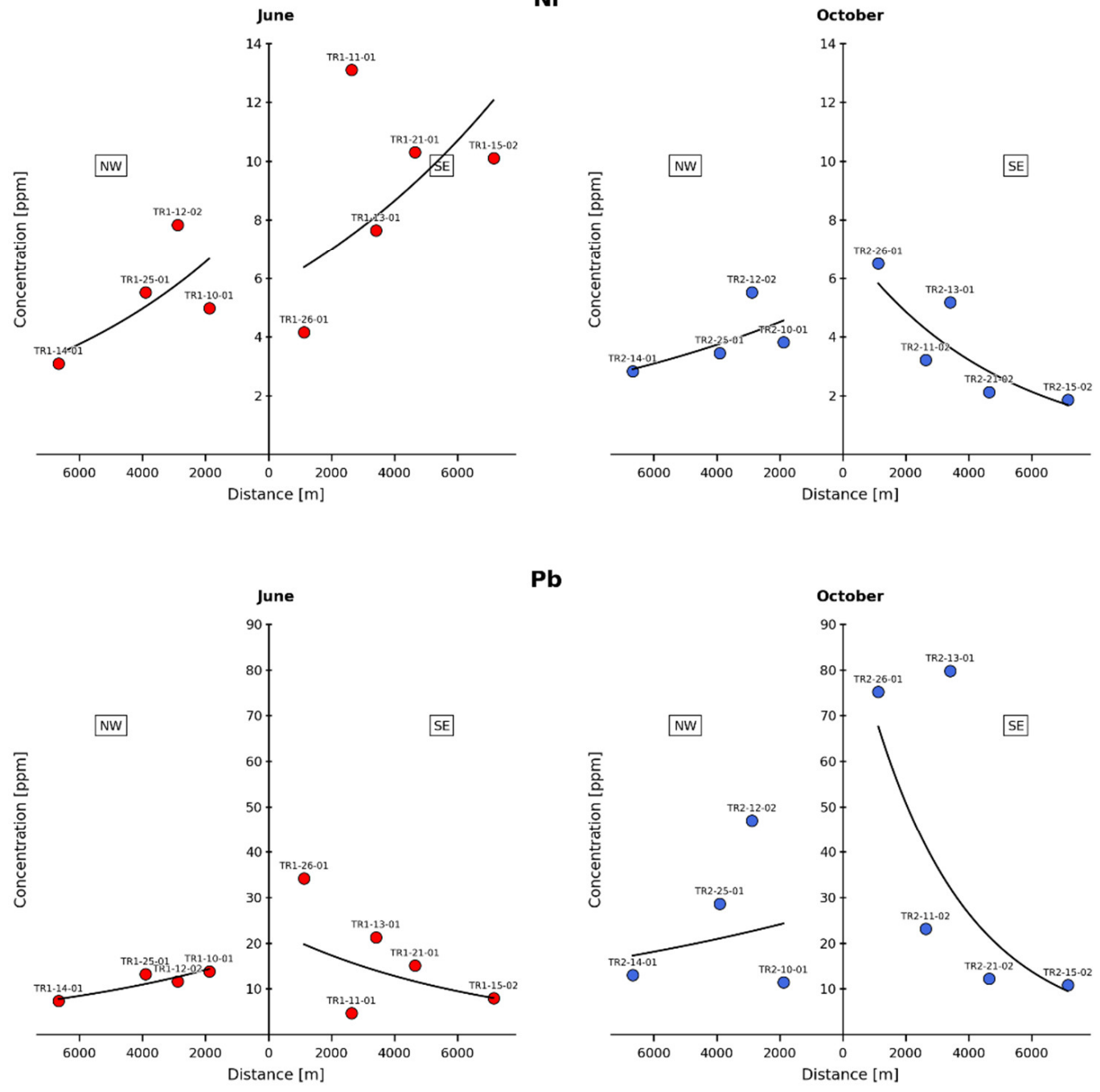

$\mathbf{P b}$
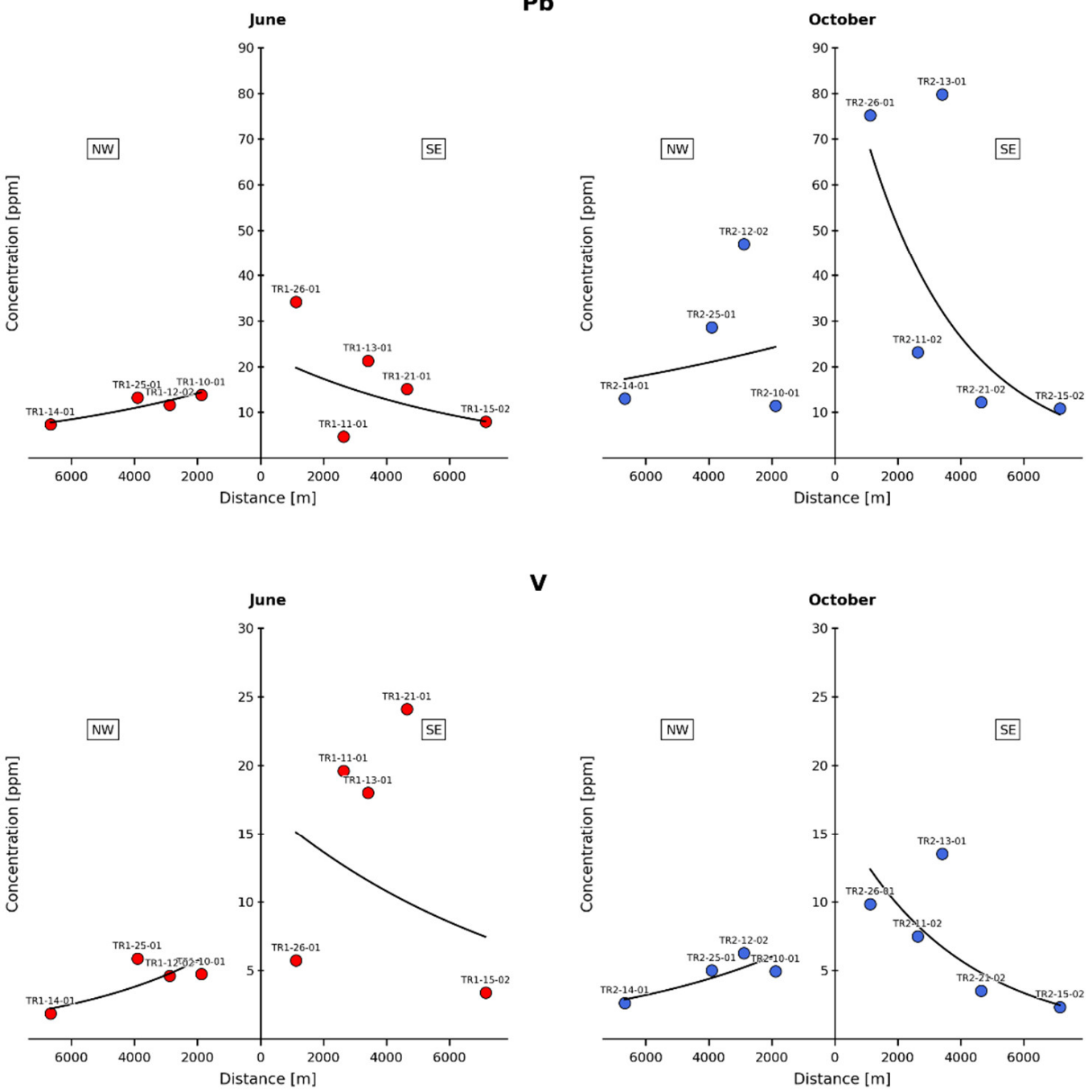

V

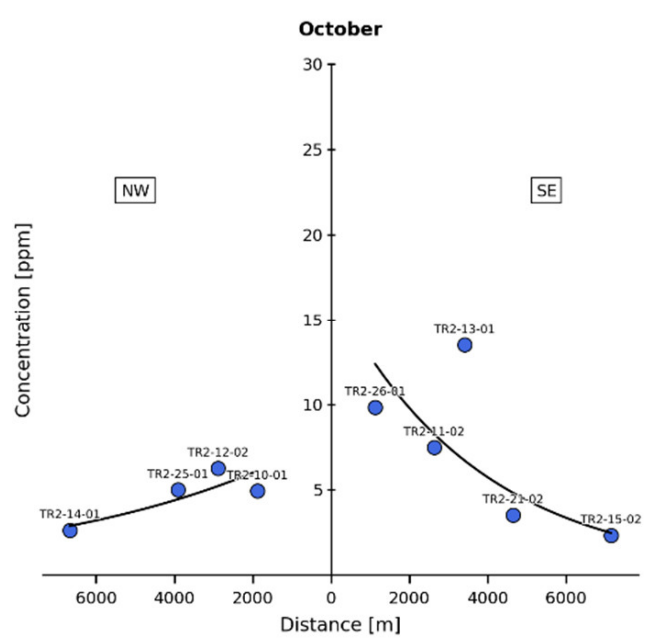

Figure A1. Cont. 

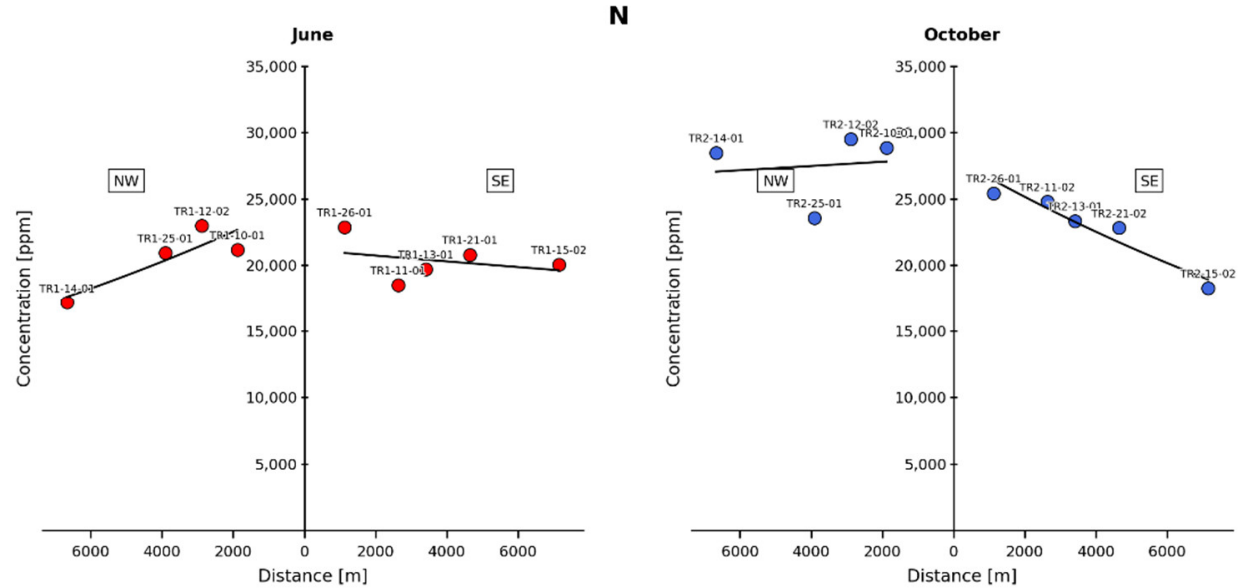

Figure A1. Gradients of concentrations of the assessed elements in terrestrial mosses collected in the surroundings of the Třinec Iron and Steel Works.

\section{References}

1. World Health Organization. Ambient Air Pollution: A Global Assessment of Exposure and Burden of Disease; World Health Organization: Geneva, Switzerland, 2016; ISBN 978-92-4-151135-3.

2. Maynard, R.; Krzyzanowski, M.; Vilahur, N.; Héroux, M.-E. Evolution of WHO Air Quality Guidelines Past, Present and Future; Weltgesundheitsorganisation Regionalbüro für Europa: Copenhagen, Denmark, 2017; ISBN 978-92-890-5230-6.

3. Czech Hydrometeorological Institute CHMI-Tabular Survey, Air Pollution and Atmospheric Deposition in Data, the Czech Republic. 2017. Available online: https://www.chmi.cz/files/portal/docs/uoco/isko/tab_roc/2017_enh/index_GB.html (accessed on 14 April 2020).

4. European Environment Agency. Air Quality in Europe: 2019 Report; European Environment Agency: Copenhagen, Denmark, 2019; ISBN 978-92-9480-088-6.

5. Hůnová, I. Ambient Air Quality in the Czech Republic: Past and Present. Atmosphere 2020, 11, 214. [CrossRef]

6. Hůnová, I. Ambient Air Quality in the Czech Republic. Atmosphere 2021, 12, 770. [CrossRef]

7. Ďurčanská, D. (Ed.) Riadenie Kvality Ovzdušia/Zarządzanie Jakością Powietrza, 1st ed.; EDIS-vydavatel'ské centrum, Žilinská univerzita v Žiline: Žilina, Slovakia, 2020; ISBN 978-80-554-1658-8.

8. Ohara, T. Long-Range Transport and Deposition of Air Pollution. In Encyclopedia of Environmental Health; Elsevier: Amsterdam, The Netherlands, 2019; pp. 126-130, ISBN 978-0-444-63952-3.

9. European Council. Directive 2008/50/EC of the European Parliament and of the Council of 21 May 2008 on Ambient Air Quality and Cleaner Air for Europe; European Council: Luxembourg, 2008; Volume L 152, pp. 1-44.

10. European Council. Directive 2010/75/EU of the European Parliament and of the Council of 24 November 2010 on Industrial Emissions (Integrated Pollution Prevention and Control); European Council: Luxembourg, 2010; Volume L 334/17, p. 103.

11. Commission of the European Union; Joint Research Centre; Institute for Prospective Technological Studies. Best Available Techniques (BAT) Reference Document for Iron and Steel Production: Industrial Emissions Directive 2010/75/EU: Integrated Pollution Prevention and Control; Publications Office: Luxembourg, 2013.

12. Ghosh, A.; Chatterjee, A. Ironmaking and Steelmaking: Theory and Practice; Eastern Economy Edition; 3. Print; PHI Learning: New Delhi, India, 2010; ISBN 978-81-203-3289-8.

13. Lin, B.; Xu, M. Regional Differences on $\mathrm{CO}_{2}$ Emission Efficiency in Metallurgical Industry of China. Energy Policy 2018, 120, 302-311. [CrossRef]

14. Cholakov, G.S.; Nath, B. Pollution Control Technologies; Eolss Publishers Co. Ltd.: Oxford, UK, 2009; Volume 3, ISBN 978-1-84826568-4.

15. Tchounwou, P.B.; Yedjou, C.G.; Patlolla, A.K.; Sutton, D.J. Heavy Metal Toxicity and the Environment. In Molecular, Clinical and Environmental Toxicology; Springer: Basel, Switzerland, 2012; pp. 133-164.

16. World Health Organization. Review of Evidence on Health Aspects of Air Pollution-REVIHAAP Project Technical Report; World Health Organization: Copenhagen, Denmark, 2013; p. 309.

17. Fortoul, T.I.; Rodriguez-Lara, V.; Gonzalez-Villalva, A.; Rojas-Lemus, M.; Colin-Barenque, L.; Bizarro-Nevares, P.; García-Peláez, I.; Ustarroz-Cano, M.; López-Zepeda, S.; Cervantes-Yépez, S.; et al. Health Effects of Metals in Particulate Matter. In Current Air Quality Issues; Nejadkoorki, F., Ed.; InTech: London, UK, 2015; ISBN 978-953-51-2180-0.

18. Seigneur, C. Air Pollution: Concepts, Theory, and Applications; Cambridge University Press: Cambridge, UK; New York, NY, USA, 2019; ISBN 978-1-108-48163-2.

19. Elichegaray, C. (Ed.) La Pollution de l'air: Sources, Effets, Prévention; Universciences. Sciences de la vie; Dunod: Paris, France, 2008; ISBN 978-2-10-051564-6. 
20. Schaap, D.M.; Hendriks, C.; Jonkers, S.; Builtjes, D.P. Impacts of Heavy Metal Emission on Air Quality and Ecosystems across Germany. Sources Transp. Depos. Potential Hazards 2018, 2018, 92.

21. Riffault, V.; Arndt, J.; Marris, H.; Mbengue, S.; Setyan, A.; Alleman, L.Y.; Deboudt, K.; Flament, P.; Augustin, P.; Delbarre, H.; et al. Fine and Ultrafine Particles in the Vicinity of Industrial Activities: A Review. Crit. Rev. Environ. Sci. Technol. 2015, 45, $2305-2356$. [CrossRef]

22. Fernández, A.J.; Ternero, M.; Barragán, F.J.; Jiménez, J.C. An Approach to Characterization of Sources of Urban Airborne Particles through Heavy Metal Speciation. Chemosph. Glob. Chang. Sci. 2000, 2, 123-136. [CrossRef]

23. Ragosta, M.; Caggiano, R.; D’Emilio, M.; Sabia, S.; Trippetta, S.; Macchiato, M. PM10 and Heavy Metal Measurements in an Industrial Area of Southern Italy. Atmos. Res. 2006, 81, 304-319. [CrossRef]

24. Saroop, S.; Tamchos, S. 4-Monitoring and impact assessment approaches for heavy metals. In Heavy Metals in the Environment; Kumar, V., Sharma, A., Cerdà, A., Eds.; Elsevier: Amsterdam, The Netherlands, 2021; pp. 57-86, ISBN 978-0-12-821656-9.

25. Markert, B.A.; Breure, A.M.; Zechmeister, H.G. (Eds.) Bioindicators \& Biomonitors: Principles, Concepts, and Applications; Trace metals and other contaminants in the environment; Elsevier: Amsterdam, The Netherlands; Boston, MA, USA, 2003; ISBN 978-0-08-044177-1.

26. Frontasyeva, M.; Harmens, H. Monitoring of Atmospheric Deposition of Heavy Metals, Nitrogen and POPs in Europe Using Bryophytes: Monitoring Manual: Survey 2020. 2020. Available online: https://icpvegetation.ceh.ac.uk/sites/default/files/ Moss\%20protocol\%20manual.pdf (accessed on 1 September 2021).

27. Harmens, H.; Norris, D.; Mills, G. Convention on Long-range Transboundary Air Pollution. In Working Group on Effects Heavy Metals and Nitrogen in Mosses: Spatial Patterns in 2010/2011 and Long-Term Temporal Trends in Europe; Centre for Ecology \& Hydrology: Bangor, Maine, 2013; ISBN 978-1-906698-38-6.

28. Harmens, H.; Mills, G.; Hayes, F.; Norris, D.A.; Sharps, K. Twenty eight years of icp vegetation: An overview of its activities. Ann. Bot. 2015, 5, 31-43. [CrossRef]

29. Schröder, W.; Nickel, S.; Schönrock, S.; Meyer, M.; Wosniok, W.; Harmens, H.; Frontasyeva, M.V.; Alber, R.; Aleksiayenak, J.; Barandovski, L.; et al. Spatially Valid Data of Atmospheric Deposition of Heavy Metals and Nitrogen Derived by Moss Surveys for Pollution Risk Assessments of Ecosystems. Environ. Sci. Pollut. Res. 2016, 23, 10457-10476. [CrossRef]

30. Frontasyeva, M.; Harmens, H. Monitoring of Atmospheric Deposition of Heavy Metals, Nitrogen and POPs in Europe Using Bryophytes: Survey 2015: Monitoring Manual. 2015. Available online: https://icpvegetation.ceh.ac.uk/sites/default/files/ICP\% 20Vegetation\%20moss\%20monitoring\%20manual\%202020.pdf (accessed on 1 September 2021).

31. Frontasyeva, M.V.; Steinnes, E. Epithermal Neutron Activation Analysis of Mosses Used to Monitor Heavy Metal Deposition around an Iron Smelter Complex. Analyst 1995, 120, 1437. [CrossRef]

32. Frontasyeva, M.V.; Steinnes, E. Heavy Metal Atmospheric Deposition around an Iron Smelter Complex Studied by the Moss Biomonitoring Technique. In Air Pollution in the Ural Mountains: Environmental, Health and Policy Aspects; Linkov, I., Wilson, R., Eds.; Springer: Dordrecht, The Netherlands, 1998; pp. 383-389, ISBN 978-94-011-5208-2.

33. Zechmeister, H.G.; Riss, A.; Hanus-Illnar, A. Biomonitoring of Atmospheric Heavy Metal Deposition by Mosses in the Vicinity of Industrial Sites. J. Atmos. Chem. 2004, 49, 461-477. [CrossRef]

34. Suchara, I.; Sucharová, J. Mercury Distribution around the Spolana Chlor-Alkali Plant (Central Bohemia, Czech Republic) after a Catastrophic Flood, as Revealed by Bioindicators. Environ. Pollut. 2008, 151, 352-361. [CrossRef]

35. Uyar, G.; Ören, M.; Yildirim, Y.; Öncel, S. Biomonitoring of Metal Deposition in the Vicinity of Eregli Steel Plant in Turkey. Environ. Forensics 2008, 9, 350-363. [CrossRef]

36. Samecka-Cymerman, A.; Stankiewicz, A.; Kolon, K.; Kempers, A.J. Bioindication of Trace Metals in Brachythecium Rutabulum Around a Copper Smelter in Legnica (Southwest Poland): Use of a New Form of Data Presentation in the Form of a Self-Organizing Feature Map. Arch. Environ. Contam. Toxic. 2009, 56, 717-722. [CrossRef] [PubMed]

37. González-Miqueo, L.; Elustondo, D.; Lasheras, E.; Santamaría, J.M. Use of Native Mosses as Biomonitors of Heavy Metals and Nitrogen Deposition in the Surroundings of Two Steel Works. Chemosphere 2010, 78, 965-971. [CrossRef] [PubMed]

38. Bačeva, K.; Stafilov, T.; Šajn, R.; Tănăselia, C. Moss Biomonitoring of Air Pollution with Heavy Metals in the Vicinity of a Ferronickel Smelter Plant. J. Environ. Sci. Health Part A 2012, 47, 645-656. [CrossRef]

39. Cowden, P.; Aherne, J. Assessment of Atmospheric Metal Deposition by Moss Biomonitoring in a Region under the Influence of a Long Standing Active Aluminium Smelter. Atmos. Environ. 2019, 201, 84-91. [CrossRef]

40. Kapusta, P.; Stanek, M.; Szarek-Łukaszewska, G.; Godzik, B. Long-Term Moss Monitoring of Atmospheric Deposition near a Large Steelworks Reveals the Growing Importance of Local Non-Industrial Sources of Pollution. Chemosphere 2019, 230, 29-39. [CrossRef]

41. European Committee for Standardization. CSN EN 16414 Ambient Air-Biomonitoring with Mosses-Accumulation of Atmospheric Contaminants in Mosses Collected in Situ: From the Collection to the Preparation of Samples; European Committee for Standardization: Brussels, Belgium, 2014.

42. Pöykiö, R.; Tervaniemi, O.-M.; Torvela, H.; Perämäki, P. Heavy Metal Accumulation in Woodland Moss (Pleurozium Schreberi) in the Area Around a Chromium Opencast Mine at Kemi, and in the Area Around the Ferrochrome and Stainless Steel Works at Tornio, Northern Finland. Int. J. Environ. Anal. Chem. 2001, 81, 137-151. [CrossRef]

43. Fernández, J.A.; Aboal, J.R.; Couto, J.A.; Carballeira, A. Moss Bioconcentration of Trace Elements around a FeSi Smelter: Modelling and Cellular Distribution. Atmos. Environ. 2004, 38, 4319-4329. [CrossRef] 
44. Varela, Z.; Aboal, J.R.; Carballeira, A.; Real, C.; Fernández, J.A. Use of a Moss Biomonitoring Method to Compile Emission Inventories for Small-Scale Industries. J. Hazard. Mater. 2014, 275, 72-78. [CrossRef]

45. Motyka, O.; Pavlíková, I.; Bitta, J.; Frontasyeva, M.; Jančík, P. Moss Biomonitoring and Air Pollution Modelling on a Regional Scale: Delayed Reflection of Industrial Pollution in Moss in a Heavily Polluted Region? Environ. Sci. Pollut. Res. 2020, 27, 32569-32578. [CrossRef]

46. Svozilík, V.; Svozilíková Krakovská, A.; Bitta, J.; Jančík, P. Comparison of the Air Pollution Mathematical Model of PM10 and Moss Biomonitoring Results in the Tritia Region. Atmosphere 2021, 12, 656. [CrossRef]

47. Kottek, M.; Grieser, J.; Beck, C.; Rudolf, B.; Rubel, F. World Map of the Köppen-Geiger Climate Classification Updated. Meteorol. Z. 2006, 15, 259-263. [CrossRef]

48. Český hydrometeorologický ústav. Univerzita Palackého v Olomouci Atlas Podnebí Česka (Climate Atlas of Czechia); Český hydrometeorologický ústav: Praha, Czech Republic; Univerzita Palackého v Olomouci: Olomouc, Czech Republic, 2007; Vydání 1, ISBN 978-80-86690-26-1.

49. Třinecké železárny, A.S. Annual Report 2019; Třinec Iron and Steel Works: Třinec, Czech Republic, 2020.

50. Czech Hydrometeorological Institute. CHMI-Tabular Survey, Air Pollution and Atmospheric Deposition in Data, the Czech Republic. 2019. Available online: https://www.chmi.cz/files/portal/docs/uoco/isko/tab_roc/2019_enh/index_GB.html (accessed on 14 April 2020).

51. Czech Hydrometeorological Institute. CHMI-Tabular Survey, Air Pollution and Atmospheric Deposition in Data, the Czech Republic. 2018. Available online: http://portal.chmi.cz/files/portal/docs/uoco/isko/tab_roc/2018_enh/index_GB.html (accessed on 14 April 2020).

52. Czech Hydrometeorological Institute Počasí: Denní Data dle Zákona 123/1998 Sb./Weather: Daily Data According to the Law No 123/1998 Co. Available online: https:/ / www.chmi.cz/historicka-data/pocasi/denni-data/Denni-data-dle-z.-123-1998-Sb (accessed on 1 September 2021). (In Czech).

53. Czech Hydrometeorological Institute. Informace o Kvalitě Ovzduší v ČR: Poskytování dat Podle Zákona č. 123/1998 Sb./Information on Air Quality in Czechia: Data Access According to the Law No 123/1998 Co. Available online: https://www.chmi.cz/files/portal/docs/uoco/historicka_data/OpenIsko_data/index.html. (accessed on 1 September 2021). (In Czech).

54. Kłos, A.; Ziembik, Z.; Rajfur, M.; Dołhańczuk-Śródka, A.; Bochenek, Z.; Bjerke, J.W.; Tømmervik, H.; Zagajewski, B.; Ziółkowski, D.; Jerz, D.; et al. Using Moss and Lichens in Biomonitoring of Heavy-Metal Contamination of Forest Areas in Southern and North-Eastern Poland. Sci. Total Environ. 2018, 627, 438-449. [CrossRef]

55. Schröder, W.; Pesch, R.; Englert, C.; Harmens, H.; Suchara, I.; Zechmeister, H.G.; Thöni, L.; Maňkovská, B.; Jeran, Z.; Grodzinska, K.; et al. Metal Accumulation in Mosses across National Boundaries: Uncovering and Ranking Causes of Spatial Variation. Environ. Pollut. 2008, 151, 377-388. [CrossRef] [PubMed]

56. Fernández, J.A.; Boquete, M.T.; Carballeira, A.; Aboal, J.R. A Critical Review of Protocols for Moss Biomonitoring of Atmospheric Deposition: Sampling and Sample Preparation. Sci. Total Environ. 2015, 517, 132-150. [CrossRef] [PubMed]

57. Meyer, M.; Schröder, W.; Nickel, S.; Leblond, S.; Lindroos, A.-J.; Mohr, K.; Poikolainen, J.; Santamaria, J.M.; Skudnik, M.; Thöni, L.; et al. Relevance of Canopy Drip for the Accumulation of Nitrogen in Moss Used as Biomonitors for Atmospheric Nitrogen Deposition in Europe. Sci. Total Environ. 2015, 538, 600-610. [CrossRef]

58. Skudnik, M.; Jeran, Z.; Batič, F.; Simončič, P.; Kastelec, D. Potential Environmental Factors That Influence the Nitrogen Concentration and $\Delta 15 \mathrm{~N}$ Values in the Moss Hypnum Cupressiforme Collected inside and Outside Canopy Drip Lines. Environ. Pollut. 2015, 198, 78-85. [CrossRef]

59. Frey, W.; Blockeel, T.L. (Eds.) The Liverworts, Mosses and Ferns of Europe; English Edition; Harley Books: Colchester, UK, 2006; ISBN 978-0-946589-70-8.

60. Vučković, I.; Špirić, Z.; Stafilov, T.; Kušan, V. Moss Biomonitoring of Air Pollution with Chromium in Croatia. J. Environ. Sci. Health Part A 2013, 48, 829-834. [CrossRef]

61. Špirić, Z.; Vučković, I.; Stafilov, T.; Kušan, V.; Bačeva, K. Biomonitoring of Air Pollution with Mercury in Croatia by Using Moss Species and CV-AAS. Env. Monit. Assess. 2014, 186, 4357-4366. [CrossRef]

62. Kolon, K.; Ruczakowska, A.; Samecka-Cymerman, A.; Kempers, A.J. Brachythecium Rutabulum and Betula Pendula as Bioindicators of Heavy Metal Pollution around a Chlor-Alkali Plant in Poland. Ecol. Indic. 2015, 52, 404-410. [CrossRef]

63. Drobnik, J.; Stebel, A. Brachythecium Rutabulum, A Neglected Medicinal Moss. Hum. Ecol. 2018, 46, 133-141. [CrossRef]

64. Dumas, J. Procedes de I'analyse Organique. Ann. Chim. Phys. 1831, 47, 198-205.

65. R Core Team. The R Project; The R Foundation. 2020. Available online: https://www.r-project.org (accessed on 1 September 2021).

66. van den Boogaart, K.G.; Tolosana-Delgado, R.; Bren, M. Package 'Compositions' 2021. Available online: https://cran.r-project. org/web / packages / compositions / compositions.pdf (accessed on 9 June 2020).

67. Templ, M.; Hron, K.; Filzmoser, P.; Facevicova, K.; Kynclova, P.; Walach, J.; Pintar, V.; Chen, J.; Miksova, D.; Meindl, B.; et al. Package 'RobCompositions' 2020. Available online: https://cran.r-project.org/web/packages/robCompositions/robCompositions. pdf (accessed on 9 June 2020). 
68. Templ, M.; Hron, K.; Filzmoser, P. robCompositions: An R-package for Robust Statistical Analysis of Compositional Data. In Compositional Data Analysis; Pawlowsky-Glahn, V., Buccianti, A., Eds.; John Wiley \& Sons, Ltd.: Chichester, UK, 2011; pp. 341-355, ISBN 978-1-119-97646-2.

69. Lê, S.; Josse, J.; Husson, F. FactoMineR: An R Package for Multivariate Analysis. J. Stat. Soft. 2008, 25. [CrossRef]

70. Husson, F.; Josse, J.; Le, S.; Mazet, J. Package 'FactoMineR' 2020. Available online: http:/ /www.jstatsoft.org/v25/i01/ (accessed on 16 July 2020).

71. Wei, T.; Simko, V. Package ‘Corrplot' 2021. Available online: https://cran.r-project.org/web/packages/corrplot/corrplot.pdf (accessed on 9 June 2020).

72. Carslaw, D.; Ropkins, K. Package ‘Openair' 2020. Available online: https:/ / cran.r-project.org/web/packages/openair/openair pdf (accessed on 17 July 2020).

73. ESRI World Imagery-Overview. Available online: https://www.arcgis.com/home/item.html?id=10df2279f9684e4a9f6a7f0 8febac2a9 (accessed on 16 August 2021).

74. ESRI World Topographic Map-Overview. Available online: https://www.arcgis.com/home/item.html?id=7dc6cea0b1764a1f9af2 e679f642f0f5 (accessed on 16 August 2021).

75. Dray, S.; Josse, J. Principal Component Analysis with Missing Values: A Comparative Survey of Methods. Plant Ecol. 2015, 216, 657-667. [CrossRef]

76. Aitchison, J. The Statistical Analysis of Compositional Data; Blackburn Press: Caldwell, NJ, USA, 2003; ISBN 978-1-930665-78-1.

77. Pawlowsky-Glahn, V.; Buccianti, A. (Eds.) Compositional Data Analysis: Theory and Applications; Wiley: Chichester, UK; West Sussex, UK, 2011; ISBN 978-0-470-71135-4.

78. Hristozova, G.; Marinova, S.; Motyka, O.; Svozilík, V.; Zinicovscaia, I. Multivariate Assessment of Atmospheric Deposition Studies in Bulgaria Based on Moss Biomonitors: Trends between the 2005/2006 and 2015/2016 Surveys. Environ. Sci. Pollut. Res. 2020, 27, 39330-39342. [CrossRef]

79. Mullineaux, S.T.; McKinley, J.M.; Marks, N.J.; Scantlebury, D.M.; Doherty, R. Heavy Metal (PTE) Ecotoxicology, Data Review: Traditional vs. a Compositional Approach. Sci. Total Environ. 2021, 769, 145246. [CrossRef] [PubMed]

80. Harmens, H.; Ilyin, I.; Mills, G.; Aboal, J.R.; Alber, R.; Blum, O.; Coşkun, M.; de Temmerman, L.; Fernández, J.Á.; Figueira, R.; et al Country-Specific Correlations across Europe between Modelled Atmospheric Cadmium and Lead Deposition and Concentrations in Mosses. Environ. Pollut. 2012, 166, 1-9. [CrossRef] [PubMed]

81. Schröder, W.; Pesch, R.; Hertel, A.; Schonrock, S.; Harmens, H.; Mills, G.; Ilyin, I. Correlation between Atmospheric Deposition of $\mathrm{Cd}, \mathrm{Hg}$ and $\mathrm{Pb}$ and Their Concentrations in Mosses Specified for Ecological Land Classes Covering Europe. Atmos. Pollut. Res. 2013, 4, 267-274. [CrossRef]

82. Schröder, W.; Pesch, R.; Schönrock, S.; Harmens, H.; Mills, G.; Fagerli, H. Mapping Correlations between Nitrogen Concentrations in Atmospheric Deposition and Mosses for Natural Landscapes in Europe. Ecol. Indic. 2014, 36, 563-571. [CrossRef]

83. Nickel, S.; Schröder, W. Integrative Evaluation of Data Derived from Biomonitoring and Models Indicating Atmospheric Deposition of Heavy Metals. Environ. Sci. Pollut. Res. 2017, 24, 11919-11939. [CrossRef]

84. Bubník, J.; Keder, J.; Macoun, J.; Maňák, J. SYMOS '97: Systém modelování stacionárních zdrojů: Metodická př́ručka; Český hydrometeorologický ústav/Czech Hydrometeorological Institute: Prague, Czech Republic, 2014. (In Czech)

85. Keder, J.; Bubník, J.; Srněnský, R. Report of the project implementation in 2002: Design of Model Tools for Objective Assessment of the State and Development of Air Pollution in Accordance with the New Air Law and EU Directives (Zpráva za řešení dílčiho projektu DP2 $v$ roce 2002: Návrh modelových nástrojů pro objektivní hodnoceni stavu a vývoje znečištění ovzduši v souladu s novým zákonem o ovzduši a směrnicemi EU); Czech Hydrometeorologic Institute: Prague, Czech Republic, 2002; p. 20. (In Czech)

86. Seibert, R.; Nikolova, I.; Volná, V.; Krejčí, B.; Hladký, D. Air Pollution Sources' Contribution to PM2.5 Concentration in the North-eastern Part of the Czech Republic. Atmosphere 2020, 11, 522. [CrossRef]

87. Hoek, G.; Beelen, R.; de Hoogh, K.; Vienneau, D.; Gulliver, J.; Fischer, P.; Briggs, D. A Review of Land-Use Regression Models to Assess Spatial Variation of Outdoor Air Pollution. Atmos. Environ. 2008, 42, 7561-7578. [CrossRef]

88. Merbitz, H.; Fritz, S.; Schneider, C. Mobile Measurements and Regression Modeling of the Spatial Particulate Matter Variability in an Urban Area. Sci. Total Environ. 2012, 438, 389-403. [CrossRef] [PubMed]

89. Filzmoser, P.; Hron, K.; Reimann, C. Univariate Statistical Analysis of Environmental (Compositional) Data: Problems and Possibilities. Sci. Total Environ. 2009, 407, 6100-6108. [CrossRef] [PubMed]

90. Suchara, I.; Sucharová, J.; Holá, M. A Quarter Century of Biomonitoring Atmospheric Pollution in the Czech Republic. Environ. Sci. Pollut. Res. 2017, 24, 11949-11963. [CrossRef]

91. Aboal, J.R.; Boquete, M.T.; Carballeira, A.; Casanova, A.; Debén, S.; Fernández, J.A. Quantification of the Overall Measurement Uncertainty Associated with the Passive Moss Biomonitoring Technique: Sample Collection and Processing. Environ. Pollut. 2017, 224, 235-242. [CrossRef]

92. Schröder, W.; Nickel, S. Moss Species-Specific Accumulation of Atmospheric Deposition? Environ. Sci. Eur. 2019, 31, 78. [CrossRef]

93. Sucharová, J.; Suchara, I. Bio-Monitoring the Atmospheric Deposition of Elements and Their Compounds Using Moss Analysis in the Czech Republic. Results of the International Bio-Monitoring Programme UNECE ICP-Vegetation 2000. Part I: Elements Required for the Bio-Monitoring Programme. Acta Pruhoniciana 2004, 77, 1-135. 
94. Sucharová, J.; Suchara, I.; Holá, M. Výzkumný ústav Silva Taroucy pro krajinu a okrasné zahradnictví; Oddělení Biomonitoringu Contents of 37 Elements in Moss and Their Temporal and Spatial Trends in the Czech Republic during the Last 15 Years: Fourth Czech bio-monitoring survey pursued in the framework of the international programme UNECE ICP-Vegetation 2005/2006= Obsah 37 prvku v mechu a časové a prostorové změny jeho hodnot v České republice během posledních 15 let: Čtvrtý český biomonitorovací prüzkum prováděný v rámci mezinárodního programu OSN EHK ICP-Vegetace 2005/2006; Výzkumný ústav Silva Taroucy pro krajinu a okrasné zahradnictví: Průhonice, Czech Republic; Nová tiskárna Pelhřimov: Pelhřimov, Czech Republic, 2008; ISBN 978-80-85116-62-5.

95. Jenner, F.E.; StC O'Neill, H. Lithophile Elements. In Encyclopedia of Geochemistry; White, W.M., Ed.; Encyclopedia of Earth Sciences Series; Springer International Publishing: Cham, Switzerland, 2018; pp. 827-828, ISBN 978-3-319-39311-7.

96. Barnes, S.-J. Chalcophile Elements. In Encyclopedia of Geochemistry; White, W.M., Ed.; Encyclopedia of Earth Sciences Series; Springer International Publishing: Cham, Switzerland, 2018; pp. 229-233, ISBN 978-3-319-39311-7.

97. Zechmeister, H.G.; Richter, A.; Smidt, S.; Hohenwallner, D.; Roder, I.; Maringer, S.; Wanek, W. Total Nitrogen Content and $\delta 15$ N Signatures in Moss Tissue: Indicative Value for Nitrogen Deposition Patterns and Source Allocation on a Nationwide Scale. Environ. Sci. Technol. 2008, 42, 8661-8667. [CrossRef]

98. Boquete, M.T.; Fernández, J.A.; Aboal, J.R.; Carballeira, A. Are Terrestrial Mosses Good Biomonitors of Atmospheric Deposition of Mn? Atmos. Environ. 2011, 45, 2704-2710. [CrossRef]

99. Sylvestre, A.; Mizzi, A.; Mathiot, S.; Masson, F.; Jaffrezo, J.L.; Dron, J.; Mesbah, B.; Wortham, H.; Marchand, N. Comprehensive Chemical Characterization of Industrial PM2.5 from Steel Industry Activities. Atmos. Environ. 2017, 152, 180-190. [CrossRef]

100. Pernigotti, D.; Belis, C.A.; Spanò, L. SPECIEUROPE: The European Data Base for PM Source Profiles. Atmos. Pollut. Res. 2016, 7, 307-314. [CrossRef]

101. Bray, C.D.; Strum, M.; Simon, H.; Riddick, L.; Kosusko, M.; Menetrez, M.; Hays, M.D.; Rao, V. An Assessment of Important SPECIATE Profiles in the EPA Emissions Modeling Platform and Current Data Gaps. Atmos. Environ. 2019, 207, 93-104. [CrossRef]

102. Robl, T.L.; Oberlink, A.; Jones, R. (Eds.) Coal Combustion Products (CCPs): Characteristics, Utilization and Beneficiation; Woodhead series in energy; Woodhead Publishing, an imprint of Elsevier: Cambridge, UK, 2017; ISBN 978-0-08-100945-1. 